Portland State University

PDXScholar

6-1-1968

\title{
Verbal accessibility between marital partners as studied in a court of domestic relations
}

\author{
Patricia Walker \\ Portland State University \\ Jan Andress \\ Mildred DeLong \\ Flora Dieckhoff \\ Sara McNeil
}

See next page for additional authors

Follow this and additional works at: https://pdxscholar.library.pdx.edu/open_access_etds Let us know how access to this document benefits you.

\section{Recommended Citation}

Walker, Patricia; Andress, Jan; DeLong, Mildred; Dieckhoff, Flora; McNeil, Sara; and Swiberg, John, "Verbal accessibility between marital partners as studied in a court of domestic relations" (1968). Dissertations and Theses. Paper 503.

https://doi.org/10.15760/etd.503

This Thesis is brought to you for free and open access. It has been accepted for inclusion in Dissertations and Theses by an authorized administrator of PDXScholar. Please contact us if we can make this document more accessible: pdxscholar@pdx.edu. 


\section{Author}

Patricia Walker, Jan Andress, Mildred DeLong, Flora Dieckhoff, Sara McNeil, and John Swiberg 


\section{AN ABSTRACT OF THE THESIS OF}

$\frac{\text { Patricia Walker, et al. for the } \frac{\text { MASTER in }}{\text { (Degree) }} \text { SOCIAL WORK }}{\text { (Major) }}$

presented on May 3, 1968

(Date)

Title: VERBAL ACCESSIBILITY BETWEEN MARITAL PARTNERS

AS STUDIED IN A COURT OF DOMESTIC RELATIONS

Abstract approved:

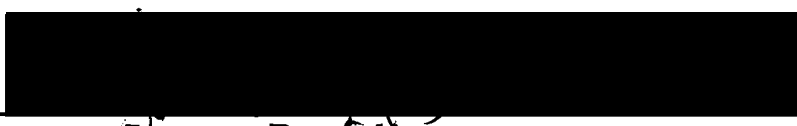

(James Breêdlove

This study investigated the concept of verbal accessibility in marriage. It is an example of the interactional approach to the study of marriage, which is concerned with the on-going socialization process in marriage. Verbal communication is one component of the socialization process and also of problem solving in marriage.

Interpersonal communication is influenced by many variables-personality, culture and social situation. Polansky (1965) conceptualized verbal accessibility as the degree of readiness to communicate verbally and to participate in communication about determinant attitudes. Determinant attitudes are tho se which have the most far reaching influence on other attitudes and on behavior.

One of the goals of this study was to develop a scale which would permit examination of the verbal accessibility of attitudes relevant for marriage, and also to measure the VA between marital 
partners. The scale of fifty-seven items covered such areas as child-rearing, sex, money, education, in-laws, religion, employment, health, and the like. The items were then roughly categorized by Goffman's scheme of social structure, interaction, and personality referents. Items were also judged as to their positive, negative and neutral connotation. Subjects were asked to report how fully they would talk with their spouses about each of the items, and also how fully they thought their spouse would talk with them about the same items. The responses were weighted in order to arrive at scores of verbal accessibility. The scale was administered to twenty-six couples who had requested conciliation services at the Court of Domestic Relations.

The scale was constructed to measure verbal accessibility in such a way that persons as well as items could be ranked along a continuum from least accessible to most accessible. Scalogram analysis with the interaction and personality items for husbands and for wives, produced a total of six scales. These scales appeared to reflect a dimension of self-protectiveness. There was no significant difference between the medians for husbands and wives, although the mean of the medians for husbands was slightly higher. Since this is in contrast to previous findings, we assumed that our sample was abnormal, biased, or both. Women did have a higher median score, for interaction items, however, which may be due 
to the woman's affective role in the family, and to the greater specificity of the interaction items. The scale appears to have potential for future use because it was able to elicit differential responses; items around such areas as sex and health had low accessibility and items around such areas as children and employment had higher accessibility.

It was hypothesized that:

1) The more similar the marital partners' verbal accessibility, the greater the likelihood of reconciliation.

2) The greater the marital partners' assumed similarity of verbal accessibility the greater the likelihood of reconciliation.

3) The higher the verbal accessibility on positive items, the greater the likelihood of reconciliation.

4) The higher the verbal accessibility on negative items, the less the likelihood of reconciliation.

5) The higher the verbal accessibility of the respondent on positive and neutral items, the greater the likelihood of reconciliation.

The data did not support the hypotheses. We concluded that our study was weakened by the small sample size, the lack of other measures of VA, and the uncertain significance of marital reconciliation. Responses apparently were biased by the stress of the situation, the desire to appear cooperative and the preponderance of female interviewers. We do not believe that the scores we obtained were actual measures of VA, but rather a reflection of the 
special situation of our subjects. Our sample appeared to have unique characterological, motivational, and interactional patterns which had an undetermined influence on our findings.

We suggest that future research consider social, cultural and personality measures as part of any study of VA. Interactional patterns, orientations to marriage and barriers to marital breakdown should also be studied. A normal sample would be useful for purposes of comparison. 
VERBAL ACCESSIBILITY BETWEEN MARITAL PARTNERS AS STUDIED IN A COURT OF DOMESTIC RELATIONS

by

\begin{tabular}{lrl}
\multicolumn{2}{c}{ Patricia Walker } \\
Jan Andress & Flora Dieckhoff \\
Mildred DeLong & Sara McNeil \\
& John Swiberg
\end{tabular}

A GROUP PROJECT

submitted to

PORTLAND STATE COLLEGE

in partial fulfillment of

the requirements for the

degree of

MASTER OF SOCIAL WORK

June 1968 
APPROVED:

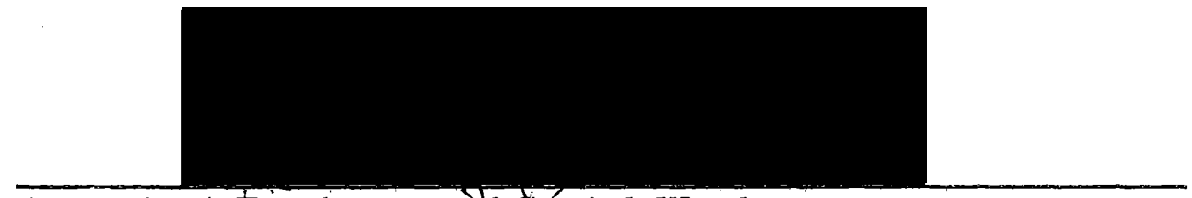

Associate Professor of Social Work



Dean, Schoff of Social Work

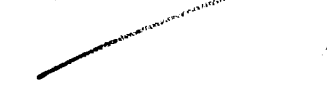

Dean of Graduate Studies

Date thesis is presented May 3, 1968

Typed by Illa W. Atwood 


\section{ACKNOW LEDGEMENTS}

We wish to express our appreciation to those whose efforts were of immense support to our project, and without whose help we could not have carried out the study. We extend our thanks to:

The Multnomah County Court of Domestic Relations Mr. Fred Hutchinson, Director of the Conciliation Service, the Counselors, and Mrs. Ruth Strejc, Secretary to the Court.

The Thesis Committee

Dr. Olive Stone, Portland State College School of Social Work; Dr. Chadwick Karr, Portland State College Psychology Department

The Advisor to the Project

Dr. James Breedlove

The Typist

Mrs. Joan Chaflin

The Participating Subjects and

The Families of the Members Participating in the Study. 


\section{TABLE OF CONTENTS}

Chapter

Page

I. INTRODUCTION I

Interactional Study of Behavior 2

The Marital Relationship 3

Problems in Marriage 5

Divorce 5

Verbal Communication $\quad 7$

II. THEORY AND HYPOTHESES ABOUT VERBAL ACCESSIBILITY 11

Verbal Accessibility and Social Work 12

Rationale for Study 13

Objectives of Study 16

Hypotheses 18

III. METHOD 26

Background : 26

Scale Construction $\quad 27$

Use of Scale 31

Sample 34

The Court of Domestic Relations 37

IV. RESULTS 40

Item Analysis 41

Scalogram Analysis $\quad 44$

Hypothesis Testing 54

$\begin{array}{ll}\text { V. CONCLUSIONS } & 60\end{array}$

$\begin{array}{ll}\text { Findings } & 60\end{array}$

Limitations of Present Study 63

The Study of Marriage and Divorce 73

Significance of VA in Marriage 76

Recommendations for Future Research 78

$\begin{array}{ll}\text { BIBLIOGRAPHY } & 81\end{array}$

APPENDIX A 86

$\begin{array}{ll}\text { APPE NDIX B } & 104\end{array}$ 


\section{LIST OF TABLES}

Table

$\underline{\text { Page }}$

I Scale Patterns for Personality Items Measuring Husbands' Self-Avowed Freedom to Communicate Feelings to Wives

II Scale Patterns for Personality Items Measuring Wives' Self-Avowed Freedom to Communicate Feelings to Husbands

III Scale Patterns for Interaction Items Measuring Husbands' Self-Avowed Freedom to Communicate Feelings to Wives

IV Scale Patterns for Interaction Items Measuring Wives' Self-Avowed Freedom to Communicate Feelings to Husbands

V Scale Patterns for Interaction and Personality Items Measuring Husband s' Self-Avowed Freedom to Communicate Feelings to Wives

VI Scale Patterns for Interaction and Personality Items Measuring Wives' Self-Avowed Freedom to Communicate Feelings to Husbands

VII Relationship Between Reconciliation and Actual Similarity of Marital Partners' Verbal Accessibility

VIII Relationships Between Reconciliation and Verbal Accessibility Measures for Husbands

IX Relationships Between Reconciliation and Verbal Accessibility Measures for Wives

X Relationship Between Reconciliation and Verbal Accessibility on Positive and Neutral Items Measures for Respondents 


\section{LIST OF TABLES IN APPENDIX B}

Table

$\underline{\text { Page }}$

XI Husbands and Wives' Median Responses to Attitude Statements

XII Responses per Interval and Median Responses of $26 \mathrm{Hu}$ sbands and $26 \mathrm{Wives}$ to Social Structure Items

XIII Responses per Interval and Median Responses of $26 \mathrm{Hu}$ sbands and $26 \mathrm{Wives}$ to Interaction Items

XIV Responses per Interval and Median Responses of $26 \mathrm{Hu}$ sbands and $26 \mathrm{Wives}$ to Personality Items

XV Range of Total VA Scores

112 


\section{VERBAL ACCESSIBILITY'BETWEEN MARITAL PARTNERS}

AS STUDIED IN A COURT OF DOMESTIC RELATIONS

\section{CHAPTER I}

\section{INTRODUCTION}

Social workers spend a great deal of their time working with families with marital difficulties. Some research has concentrated on understanding why some marriages are satisfying and lasting and other marriages are unsatisfactory and terminate in divorce. The difficulty of learning more about marriage is partially due to the privacy which surrounds marital interaction (Burgess, 1926; Mayer, 1967). Due to this difficulty, much of our information regarding marital interaction is gained at times of crisis such as divorce and separation.

This is the third of a series of studies about one aspect of verbal interaction in marriage. The first study "Marital Interaction Theory: Some Implications for Research" (Pugh, et al ., 1966) reviewed the interactional approach to the study of marriage. "A Scale of VA in Marriage" (Kresse, et al. , 1967) attempted to develop an instrument for clarifying one concept, verbal accessibility in and about marriage. The specific intent of the current study has been to investigate the readiness of marital partners to discuss with their 
spouses feelings regarding various significant aspects of their relationship.

\section{Interactional Study of Behavior}

Burgess (1950) and others have emphasized that the actual unity of family life has its existence in the interaction of its members. Interaction may be verbal or non-verbal, but as Weis and Monroe (1959) point out, ". . interaction implies the action of one person and the response of another" (p. 5). The interactional approach, which has been utilized in this study, is concerned with continuing adult socialization processes and personality development. Stryker (1959) defines socialization as the process by which ". . . the human organism acquires the ways of behaving, the values and attitudes of the social units of which he is a part" (p. 111). He defines personality as ". . . the organization of persistent behavior patterns" (p. 112).

Marriage requires modifications of behavior and attitudes for both partners. Typically, this change process begins during courtship. Each partner brings his individual heritage of values, norms, and attitudes. Each attempts to influence the other; and if harmony is to be achieved, each must modify or change some of his attitudes and probably some of his behavior. Role behavior is one important area in which change is required. 
Bell (1963) speaks of two basic role adjustments. First, he notes the need to ". . achieve some basic agreement between an individual's own marital role expectations and his own personality needs" (p. 268). A second area of adjustment is between the role perceptions of the person filling a particular role and his spouse's concept of the role. Also important is the interactional nature of the partners' roles in terms of mutual satisfaction and compatibility. These tasks of the spouses are approached through both verbal and non-verbal interaction.

\section{The Marital Relationship}

"Marriage as human behavior may be defined as the union, sanctioned by society, of man and woman as husband and wife" (Burgess and Locke, 1950, p. 6). Although the marital relationship does have qualities found in some other relationships, it is also characterized by features, suggested in the above definition, which are unique to marriage. Marriage has a public and binding nature, and dissolution is therefore under legal control. The members of this union live together, and this physical proximity intensifies involvement in the relationship. This living arrangement means that individual and sex differences become important, and the self is exposed. Marriage is also unique in that the relationship is likely to result in children. Other lives must then be considered. The 
family provides the primary education of the children in social habit, customs, and basic knowledge. Parents initiate the socialization process and personality development. Male and female role learning also begins at home. Thus, society has a real investment in the continuance of the marital relationship for the transmission of the culture.

In spite of the importance of marriage to our culture there is little explicit preparation for this relationship. A typical person entering marriage has only his own observations of his parents' marriage as a guide. Obviously, an individual whose parents had a poor or a dissolved marriage would tend to have some biased conceptions. Even the person who does have a "desirable model" faces certain cultural influences in marriage. Montagu (1956) includes as sources of marital tension in our culture: 1) marriage based upon the concept of romantic love which leads to disillusionment, 2) lack of distinct division of labor between husband and wife, 3) social mobility which requires adjustment to the customs and values of the spouse's class, and 4) the complexity of marital roles our society demands. More realistic and adequate preparation for marriage might help couples later resolve some of the inevitable problems of marriage. 
$\underline{\text { Problems in Marriage }}$

A great deal of interest has been centered upon the area of marital problems. Generally, stress sources may be categorized in three ways: "l) external stress (including stresses originating from non-marital family members), 2) internal or intrapsychic stress, and 3) interpersonal or interactive stress" (Roberts, 1965, p. 6). Differences can become a source of stress and may be a divisive factor in the marital relationship. Differences have been classified into various areas. One author suggests ". . religion, social life, mutual friends, in-laws, money, and sex relations as important differences" (Landis, 1946, p. 676). Blood and Wolfe (1960) suggest ". . . money, children, recreation, personality, inlaws, roles, religion, politics, and sex" (p. 677) as potentially stressful areas. Conflict is, of course, inevitable in marriage. Another vital consideration ". . . is the pervasiveness of conflict in terms of the marital relationship... in terms of the family as a whole and... its effect on social relationships with neighbors, relatives, and others" (Roberts, 1965, p. 8).

\section{$\underline{\text { Divorce }}$}

Inability to resolve differences or to make necessary changes may lead to divorce action. Several studies have revealed that 
divorce is not only more frequent today than in previous generations, but it is also likely that it is resorted to more hastily after marital difficulties arise (Jacobson, 1959). The United States had the highest divorce rate among Western nations. "In 1963, there were 258 divorces per 1000 marriages in the United States" (Goode, 1966, p. 498).

In an integrative review of empirical findings concerning divorce, (Levinger, 1965) suggests a scheme based on a hypothetical conception of the attractions, distractions, and barriers in marriage. Factors which tend to attract the partner to continuance in the marital relationship include: esteem for spouse, desire for companionship, sexual enjoyment, adequacy of husband's income, similar social status, and home ownership. Also, the amount of a man's education has been found to be higher for durable than for dissolved marriages.

Forces which may pull the spouse away from continuing a marriage include: preference for another sex partner, kin affiliations that undermine marital unity, and the wife's opportunity for independent income (Levinger, 1965).

A study of five hundred couples done in the Los Angeles County Conciliation Court in 1960, lists complaints in rank order:

The wives' complaints were: 1) money management (hu sband withholding financial information), 2) infidelity, 3) loss of 
affection, 4) bad temper, 5) excessive drinking, 6) sexual problems, 7) physical abuse.

The husbands' complaints were: 1) money management (wife irresponsible with money), 2) interferring in-laws, 3) nagging, 4) infidelity, 5) refusal to talk over problems, 6) bad temper, 7) sexual problems (Green, 1963, p. 320).

Levinger (1965) refers to "sources of barrier strength to marriage dissolution" (p. 24). These include obligations to dependent children, marriages in which both members are Catholics, Jews, or reasonably strict Protestants, joint church attendance, parental encouragement to continue the marriage, community stigma, and inadequate funds for court costs and lawyers' fees.

\section{Verbal Communication}

Verbal communication under certain circumstances may play a key role in creating as well as in resolving marital problems. Communication is defined according to Ruesch and Bateson (1951) as ". . all those processes by which people influence one another"

(p. 6). They describe four levels of communication as intrapersonal, interpersonal, group and cultural. Emphasis in the current research is placed on the interpersonal communication between husband and wife. Interpersonal communication is characterized by an exchange of receiving, transmitting, and evaluating messages. If distortion in the transmission process takes place, continued exchange would ideally enable a direct correcting of the message. This correction 
process has been conceived by Ruesch and Bateson as complementation, which "... is never complete..... The human individual can never perceive himself perfectly in relation to others" (p. 280).

Research has to rely heavily on verbal expression, but we recognize the role that non-verbal expression plays in communication. Facial expression, stance, and posture are all tacit means of expression. In the sexual area, for example, non-verbal communication seems to be far more elaborate than verbal communication (Bernard, 1964).

One mode of changing attitudes and behavior is through verbal means. Partners may express expectations, resolve differences, and facilitate adjustment through verbal communication. Such marital interaction can result in shared meanings. Katz (1965) found that couples seeking help for marital difficulty were more discrepant in the meanings that they attributed to concepts relevant for marriage than couples not involved in conflict. For instance, happily married spouses seemed in greatest agreement and the unhappy spouses in least agreement in their meaning of the concepts "husband, "wife," and "sex relations."

Ichheiser (1949) raises some interesting questions regarding communication. When communication occurs does it do any good? How can quality be measured? Under what conditions is exchange helpful or a hindrance? If people are culturally dissimilar, perhaps 
interaction will emphasize differences rather than helping them become more similar. There is also the question of how well people should get to know each other. At what point does communication become so revealing that an individual feels his identity is threatened? Ichheiser builds a conceptual scheme around the idea of the visible and invisible aspects of personality. The visible aspects are much more exposed to social pressure and control. The "image" which a person "projects" about himself is that with which others communicate.

A person has a tendency to stabilize his image of another person's personality. Certain characteristics become automatically attributed to a person. Likewise, these images are dynamic factors which control the behavior of the individual. With regard to distortion of the image, not only do external controls tend to distort an individual's image, but it may also be further distorted and controlled by false social perceptions; Ichheiser suggests that these "illusions" have social utility:

It is highly probable that certain illusions possess a positive function and value. It remains a question whether all human relations would always operate more smoothly or with greater satisfaction if they were altogether freed from illusions. Perhaps some degree of illusion is a necessary as well as an inescapable element in the complexities of our life (p. 35).

It certainly seems possible that during courtship the significant interaction is on the level of the visible personalities of the 
participants. The invisible factors becoming visible after marriage may either place a strain on the marital relationship or strengthen that relationship.

Communication is a critical component as the visible and invisible factors become operational in the process of adaptation to marital roles. If one is to adapt to his marital partner, he must be alert to the verbal and non-verbal expressions or communications. Verbal communication is withheld, distorted, or presented in a forthright manner as trust is or is not established in the marriage.

One aspect of verbal communication--verbal accessibility-is described by Polansky (1965) as the readiness to communicate determinate, or important attitudes. Dependent, or less influential attitudes, are related to and controlled by the determinate ones, and both are relevant to all aspects of family and marriage situations. Thus, the study of verbal accessibility has importance to those in the profession of social work. 


\section{CHAPTER II}

\section{THEORY AND HYPOTHESES ABOUT VERBAL ACCESSIBILITY}

The purposes of this study were twofold. The first was to develop a scale of verbal accessibility. The second was to study the relationship between verbal accessibility and conciliation efforts of couples whose marriages were in jeopardy.

Polansky (1965) defines verbal accessibility (VA) as the readiness of a person to communicate verbally and to participate in communication about his most important, or, determinant attitudes. Determinant attitudes are those whose change seems most likely to bring about significant changes in other related attitudes. The result would be an alteration of the personality. Polansky (1965) further notes that a person will not communicate to the same depth on all attitudes but that determinant attitudes will be less accessible than less "influential" attitudes. He further points out that the amount of verbal flow, that is, verbosity, is not related to the depth of disclosure in which one is able to participate. In fact, it has been noted that verbosity might be used by the person as a protection from the threat of self-disclosure. Cognizant of verbal flow as a defense, Polansky (1965) describes the chief components of verbosity as:

(a) a concentration on the current reality in a stimulus bound fashion; (b) an over-scrupulosity about detail . . . ; (c) a desire to re-experience things past through retelling 
them . . ; (d) a desire to say something hostile while not saying it...(p. 31).

From the Polansky (1965) studies, it appears that VA is dependent on two variables: 1) the release of inhibiting factors in a given situation and 2) the enduring characteristic s of the individual.

\section{Verbal Accessibility and Social Work}

Interpersonal competence, a concept promoted by Cottrell and Foote (1955), is one aspect of personality structure which sets limits on the quality of marital interaction. Interper sonal competence denotes capabilities to meet and deal with a changing world, to formulate ends, and to implement them. Competence can insure effective interaction in achieving common goals as well as individual self-expression and development. Closely bound to this ability is the capacity to detach oneself from immediate instincts or stimuli in order to plan and create. This involves one's ability to use symbols, such as language symbols, in a useful way. In discussing personality, the suggestion is made by Kresse, et al. (1967) that personality is a major determinant in marital interaction and that competence in marital interaction involves a person's capacity for response to the other. Considering that interaction is the reciprocal activity between two persons, it becomes apparent that the higher the degree of competence in interpersonal exchange, the greater will 
be the understanding of the needs and expectations of the marriage partner.

Personality, with its various components such as ego development, thought development, language skills, and so forth, comprises the basis for interpersonal competence. Both partners are equally important in establishing and maintaining the marriage relationship. Polansky (1965) states that the verbal accessibility of personality appears to be indicative of general ego functioning.

Because interpersonal relationships and the functioning of the individual in his social systems is the concern of the social worker, it is hoped that research in the field of communication within marriage might facilitate greater success in the helping relationship. Marriage is the most intimate of social systems, and the effects of the marriage on the individual and the individual on the marriage are concerns of professionals working with persons who need help in improving their social functioning. We, therefore, consider an understanding of verbal accessibility in marriage of major importance to the helping professions.

\section{$\underline{\text { Rationale for Study }}$}

The rationale for studying VA in marital interaction is:

1. VA is an important aspect of verbal communication. Polansky (1965) suggests that loneliness and alienation in some 
marriage relationships may be due to the lack of readiness of one or both spouses to discuss determinant attitudes.

2. VA is important to marriage as an ongoing socialization process. Readiness to express oneself facilitates adaptation and mutually satisfying ways of behaving. Socialization is the process by which the human organism acquires the ways of behaving, the values, norms, and attitudes developed through life situations from birth (Stryker, 1959). Thus, one responds in particular ways, at times similar, and at times dissimilar, to the responses of his partner. The man-wife relationship with the inherent factors of social, emotional, and physical intimacy makes apparent the differences. It becomes necessary for individual behavior, attitudes, and expectations to be altered to some extent as the differences become apparent and as each partner evaluates his own expectations in relation to those of his spouse.

One very important adjustment that has to be made by many couples early in marriage is the redefining of their experiences, premarital role expectations on the basis of newly experienced reality (Bell, 1963, p. 280).

Thus we see that verbal communication is an important means of expressing role expectations, resulting in the movement toward (or possibly, away from) greater marital satisfaction.

3. VA is related to personality, which is a major determinant in marital interaction. 
We do seem to have in view a facet of personality which is relatively stable and which either determines important areas of functioning, or is closely associated with the per sonality dynamics which do (Polansky, 1965, p. 23).

4. VA may be important for the growth of love in marriage.

As Jourard states:

You cannot love another person, that is, behave toward him so as to foster his happiness and growth, unless you know what he needs. And you cannot know what he needs unless he tells you (Jourard, 1964, p. 3).

5. VA is related to the organizational unity or disorganization of the personality of each marital partner. "Organizational unity ... implies: 1) an adequate degree of differentiation (of attitudes) together with 2) competent psychic apparatuses for coordinating disparate drives, etc." (Polansky, 1965, p. 18). If a person is unable to differentiate his feelings or affects, he would be unable to express them. If a person is unable to synthesize conflicting attitudes into one, he may not be able to verbalize them at all. Thus the burden of communication may fall on non-verbal rather than verbal techniques.

6. The personal attributes of ego and self-image affect VA and the marriage relationship. Spitz (1957) attempts a conceptual distinction between self and ego. He sees the ego functions of synthesizing, organizing and integrating as vital to adaptation.

Self is a product of awareness, which is an ego function. Self is predicated on the realization of separateness, of being an 
individual; and is developed in the give and take of interaction in the past, and affects willingness to "express oneself" in the present or future. Fear of self disclosure inhibits verbal accessibility by forming a barrier to close relationships. Silence might reflect a sense of inadequacy and worthlessness, which might prevent a healthy marriage relationship from developing.

7. VA reflects the development of thought. Vygotski (1962), in his study of thought and language, traces the interrelationship between thought and speech development in the adult. Using this concept, Polansky (1965) states that ". . . the quality of thought determines the quality of language, but the quality of language may affect the upper limits of the development of thought" (p. 39). Polansky concludes by stating that:

A very large proportion of the population operates, even in adulthood, on a level of thinking which is not highly rational or objective and with speech that has remained preintellectual (p. 40).

Stunted growth in the area of thought development, then, limits the use of language, and ther efore reduces greatly the use of speech in the important business of problem solving.

\section{Objectives of Study}

This particular study was designed, first, to develop a scale of VA which would indicate some communication patterns in marriage 
between husbands and wives. Our objectives were: 1) to develop a scale of content areas with variable accessibility; 2) to develop some unidimensional scales; 3 ) to study the relative accessibility of positive and negative items.

The second set of objectives was to determine the relationship between verbal accessibility and the probability of a marital pair reconciling following services provided by a Court of Domestic Relations. If the hypotheses were validated, the scale of VA which had been developed for this study could be used to predict the likelihood of reconciliation by those couples who have agreed to consider reconciliation services. It was hoped that this study would provide an index by which a counselor might predict the outcome regarding reconciliation, with or without counseling. It was recognized that certain objective factors, as determined by other studies, are associated with the durability of marriage. Such factors include age differences, ages at marriage, religious differences, income, education, and socio-cultural-economic background. How one feels about discussing attitudes pertaining to variables such as, or similar to, these within the marriage was the concern of the present study. Prediction of marital success and/or the probability of reconciliation based on these objective facts may be enhanced when patterns of interaction in the marriage are taken into account. 


\section{Hypotheses}

It would appear that if a couple has more things in common than in conflict and each spouse responds and communicates with his partner in a similar fashion, the more likely that there will be success or compatability in marriage. It is pointed out by Kernodle (1959) that homogamy, the tendency for like to marry like, is a cultural expectation in our society. He examined such characteristics as temperament, social and cultural background, age, race and ethnic group, previous marital status, interests, religion, and intelligence and found in every instance that difference over chance expectation was in the direction of homogamy rather than heterogamy.

Breedlove's (1962) findings indicate that the more similar the partners are in what they prefer to discuss with each other, the more likely they will be to satisfy each other's needs for approval, affection and self esteem.

Based on these observations, we hypothesized that:

Hypothesis I. The more similar marital partners'verbal accessibility, the greater the likelihood of reconciliation.

Assumed similarity (attributed consensus) is a term used to describe the degree to which one person perceives another to be like him. This is a concept of wide concern in studies of human relationships. 
Jourard (1964) states:

- . to be open, or transparent to others, seems to be a necessary condition for being open to oneself. Knowing oneself and being known by another appear to be correlated. To the extent that vivid cognition of one's own experiencing is a factor in behavior that sustains wellness, and to the extent that knowing oneself and being known are correlated, we can see intimations of a complex relationship between self-disclosure and health (p. 185).

While it is recognized that all partners of marriages in distress are not beset with illness, mental or physical, the above observations bring one to ask whether a healthy marriage is related to under standing oneself and one's partner fairly equally.

Studies by Steiner (1955), Smith (1958), Breedlove (1962), Burdick and Burnes (1958), confirm a positive relationship between assumed similarity and attraction toward another person. Such evidence reinforces the belief that there is a general tendency for a person to "see" another person as similar to himself when he has strong positive feelings toward that person and to view as dissimilar those whom he dislikes. Their findings indicate that if a person sees himself as having qualities similar to another he expects the other to behave in a manner similar to his own. He would find himself attracted to one whom he felt similar. Steiner's (1958) study introduced a "frustrating experience" as an influencing factor and found that this accentuated the tendencies to dislike and, therefore, to assure greater differences. 
These findings support an interesting study by Fiedler (1954) on the correlation between effectiveness and assumed similarity of team members. The team members were basketball players and teams of surveying students. His findings support the belief that group effectiveness is related to the interpersonal perceptions which members of the group have toward one another. The results of the study showed that as sumed similarity of the most preferred coworker in surveying and possibly also in basketball is related to team effectiveness. Fiedler further states that low assumed similarity is thought to reflect lack of emotional involvement with teammates and task-oriented attitudes. These findings support and correlate with the studies of marriage relationship, as reviewed above. We, therefore, hypothesized that:

Hypothesis II. The greater the marital partners' assumed similarity of verbal accessibility, the greater the likelihood of reconciliation.

In considering the ways in which people express themselves, it becomes apparent that negative or unpleasant, and positive or pleasant feelings are both verbally accessible in varying degrees and that there may be some relationship between the degree of satisfaction in marriage and the VA of the se positive and negative attitudes. The question is whether a person who is considering divorce or sees the marriage as threatened will have developed a pattern of 
concentrating on and communicating about negative feelings and facts in the marriage, or if the reverse is true; or if there is, in fact, no connection between accessibility as regards negative and positive feelings and the dissolution of the marriage. We, therefore, designed the questionnaire in such a way as to reflect the readiness of marital partners under stress to communicate their feelings in both positive and negative areas.

When considering the communication patterns of married partners, personal observation indicates that when couples appear to be functioning well and appear satisfied with their marriage they seem to feel and express positive feelings about themselves and the relationships in which they find themselves. Generally speaking, people who are enjoying success in many areas tend to think and speak positively. The opposite appears to be equally true; people who are not functioning well and do not seem to be enjoying success tend to be negative in their thinking and communication with others.

There is no reason to believe that in a marriage relationship these observations would be less true. Marriage, because of its nature, must withstand more stress than other relationships, and it must necessarily withstand some negative communications. It appears that the more dissatisfied one is with his marriage the more negative feelings he will have about his spouse. When a couple is in a state of crisis that might result in consideration of divorce, there 
could be a high level of negative thought and communication.

In a recent study conducted by Levinger and Senn (n.d.) at the University of Massachusetts, fifteen married couples who were clients of a family agency and who were undergoing counseling for marital or child difficulties were compared with seventeen couples who were elementary school parents not having family difficulties. The statistics for both groups, agency and school couples, were comparable as to duration of marriage, number of children, and socio-economic background. The findings indicated that:

- . marital satisfaction was less related to the proportion of unpleasant than to that of pleasant disclosure; also, frequency of unpleasant disclosure was far higher in the Agency than in the School sample" (Levinger \& Senn, n.d., p. 9).

In a separate study conducted by Levinger (1965), it was revealed that the more satisfied spouses showed less tendency to discuss negative feelings, particularly when these feelings pertained to their mates; however, these same spouses were more likely than the less satisfied ones to discuss unpleasant feelings about external events, such as a bad day at work.

Levinger (1965) states that it appears to be true that people tend to communicate more readily and frequently about "positive" matters than about "negative"matters.

We therefore, hypothesized that: 
Hypothesis III. The higher the verbal accessibility on positive

items, the greater the likelihood of reconciliation.

Jolesch (1962) points out the fact that when the marriage is under stress, the feelings expressed by one or both of the marital partners are either negative or of bewilderment in the initial interview. Inasmuch as the sample in the present study is made up of couples in a stress situation, it appears likely that negative feelings would be expressed to a greater degree than positive feelings.

We, therefore, hypothesized that:

Hypothesis IV. The higher the verbal accessibility on negative items, the less the likelihood of reconciliation.

Karr (1966) conducted a three '-year study (1964-1966) of conciliation service at the Multnomah County Court of Domestic Relations, Portland, Oregon. Some pertinent facts were discovered regarding communications and feelings in marriages under stress as they relate to statistics on reconciliation. Some of these findings, as yet unpublished, relate to the present study.

In Multnomah County, the larger proportion of those filing petitions for conciliation service are husbands, the ratio being five to four. While the wife more frequently files for the divorce, this does not necessarily indicate that she is the one who wants to dissolve the marriage; she is frequently manipulated by her husband 
into taking the action. Whichever partner files for the divorce usually becomes the respondent to the petition for conciliation services. Not all of the couples who petition for counseling services do so following the filing of divorce complaints; sixty-eight percent of male petitioners and thirty percent of the female petitioners do so following filing of divorce complaints by the partner. Karr's findings show that it is the attitude of the respondents that usually deter mine the outcome of conciliation services. Of one hundred female respondents answering the question, "Do you want to reconcile?", seventy-three who had answered "no" had not reconciled although twenty-five were still undecided. Of those twenty-one who had initially answered "yes," fourteen had reconciled, one had refused, and six were still undecided. These figures represent the results forty-five days following the time of the initial interview.

Of the one hundred male respondents who answered the question "Do you want to reconcile?", sixty-one had initially answered "yes," forty reconciled, twenty-four refused reconciliation, and eleven were still undecided. Thus, the respondent is usually the key person who determines the outcome. If the respondent indicates some positive feelings regarding the marriage relationship (by answering "yes" to the question "Do you want to reconcile?"), there is a greater likelihood that reconciliation will be effected.

Forty-three and four-tenths percent of the couples who 
petitioned for concilation services see communication as a contributing problem in the marriage, but not as the focal problem in the breakdown of the marriage relationship.

Another significant finding in the Karr study shows that when the respondent sees in himself failures in communication skills, the couple is more likely to reconcile. This would indicate that as the respondent looks to himself/herself for some of the causes, he concentrates less on the shortcomings of the partner. Twenty percent of the female respondents in the study say their communication is a problem; thirty percent of the male respondents say communication on their part is a problem.

We, therefore, hypothesized that:

Hypothesis V. The greater the verbal accessibility of the respondent on positive or neutral items, the greater the likelihood of reconciliation. 


\section{CHAPTER III}

\section{METHOD}

This study of the readiness to communicate in marriage had as one of its principal aims the development of a scale to measure the verbal accessibility of marital partners to each other. A previous study, Kresse, et al. (1967), provided a basis for the present research. The study by Kresse, et al. examined VA in and about marriage. We chose to study the communication of marital partners with each other and excluded any study of their communications with friends, relatives, or the counselor with whom they were involved.

\section{$\underline{\text { Background }}$}

The study by Kresse, et al. as well as research studies by Jourard and Lasakow (1958), Komarovsky (1964), and Polansky (1965), served as background resources for development of our scale. As we reviewed this literature about VA and about marriage, our initial attention was directed to the questionnaire of Jourard and Lasakow (1958), which was designed to measure the amount and content of self-disclosure to selected "target persons." We adapted this questionnaire for use with marital pairs.

As the task of development of the scale proceeded, Goffman's (1959) concept of "impression management": life situations, 
concern or unconcern for how they appear to others, real and imagined feelings of shame, ambivalence about feelings of self or others, playing roles to please or confound others played a major part in the selection and elimination of items. We followed his descriptive baselines of social structure, interaction, and personality as related to the performance or functioning of an individual.

In order to approach one of our goals--items reflecting intimate areas--in construction of the scale, the research report of Taylor and Altman (1966) was used to estimate the intimacy scale values of items having to do with such areas as religion, money, sex, marriage, and parental family.

The original decision was made to study a sample of approximately fifty couples from the Court of Domestic Relations, Multnomah County, Oregon, who were involved in the conciliation process. Unfortunately, lack of time limited the study to only twenty-six couples.

\section{Scale Construction}

An attempt was made to develop scale items that would be comprehensible, unambiguous, succinct, and representative of the various aspects of marriage, particularly intimate areas. Edwards' (1957) criteria for editing research items were used to ensure the first three qualities. Jourard and Lasakow's (1958) self-disclosure 
questionnaire was used as a guide for development of the original twenty-one items. We elaborated on these items from readings and observations to establish an item pool of over one hundred items related to work, religion, physical and mental health, emotions, relationships with in-laws and parents, and intra-family and marital relationships. By elimination of items that might be similar and, then, items less intimate in context as described by Taylor and Altman (1966), the questionnaire was reduced to sixty items. To provide greater representativeness, we made a general use of Goffman's (1959) concepts of social structure, interaction, and personality and related them to the marital role. "Social structure" is concerned with how the family is viewed by the public; "interaction," with role expectations within and without the marital situation; and "personality," with one's concept of self.

Following the pre-test at CDR, three of the total of sixty selected items were changed in form or content so that all of the sixty items for presentation to both husbands and wives would be similar in character for the final study.

Because two items were mislabeled and one discarded for lack of agreement on content, the final total number of items used for recording responses was fifty-seven. Of the fifty-seven items, seventeen were considered to be items having to do with social structure, twenty-five as interaction items, and fifteen as items 
related to per sonality.

The sixty items administered to subjects were adjudged, by independent polling of each of the research group members, to fall into the content areas of positive, neutral, or negative. At least four of the six members had to be in agreement regarding the content of an item before a positive, negative, or neutral sign could be assigned, One item had to be discarded in this process. "Successes in your work" was designated a positive item; "His/her ways of disciplining the children"was judged to be a neutral item; and "Fears that you may have a nervous breakdown" was placed in the category of negative items. On the VA Score sheet in Appendix A, the forty negative items have no symbol. Positive items have a "+" sign, and neutral items a "0" as a symbol. There were ten positive items, seven neutral items, and forty negative ones.

In preparing the final scale, we were aware of the preponderance of negative items but believed that those items were more representative of the daily situations that marital partners would need to discuss for an enduring, reasonably successful relationship. Also, we adjudged these items to cover problematical areas that would arise in marital conflict.

In the previous study, the stem form used to introduce the item was: "Suppose that you had this feeling or concern...". This stem form seemed to introduce the element of "make believe" 
and seemed not to bring about the investment of the subjects in the scale that we hoped to attain. Since our study was focused on the marital pair and was designed to attempt to measure the VA of each to the other, the following stem form was chosen: "How much would you be willing to talk with your husband/wife about your feelings concerning . . " or "How much do you think your husband/wife would be willing to talk with you about his/her feelings concerning . . ". It was hoped that the emphasis placed on the element of feelings would elicit more sensitive responses from the subjects. During July and August, 1967, seven couples took part in the pre-test of the schedule. At that time, each subject was asked to rate only himself with respect to his verbal accessibility. The instructions to the subjects taking part in the pre-test were almost identical to the Instructions to Subjects shown in Appendix A, except that these subjects were not asked to give an opinion about their partners' responses in the pre-test. Thus, Part II of the instructions was not presented at this time.

In the previous study, Kresse, et al., the counselor at the Court of Domestic Relations and at the Family Counseling Service was a "target person" for responses of the subjects. We hoped to avoid the predilection of subjects to present themselves in the best manner to the counselor and to obtain more discrete responses from our CDR subjects by informing them, through the instructions, that 
the questionnaire would not be graded or evaluated by anyone nor affect the counseling for which they had come.

\section{Use of Scale}

Prior to administration of both the pre-test and the final test, the items to be presented to each of the marital partners were randomized so that they would not appear in order of sensitivity. The items for the husbands and the wives and the randomized items for rating of their spouses appear in Appendix A. In all, four separate scales were used, and each subject was provided with two decks of cards for the test.

After the instructions to subjects were presented, the interviewer read aloud the items from the mimeographed sheets as the subject read the card with the same item that was before him in a deck. A small box with slots designating the responses of "Completely," "A Lot," "A Little" or "None" had been placed before the subject, who then deposited the card in the slot labeled with the most appropriate description about how much he would talk with his partner about the item. The same box was used by the subject to estimate how much he thought his marital partner would talk with him about a similar variety of items.

Time for instruction and presentation of 120 items in all (two questionnaires of sixty items each) did not consume more than 
one-half hour per subject. It was not felt that the test situation produced fatigue or boredom.

The subjects were assigned to each of the interviewers according to the availability of the latter. The subjects were involved in the conciliation process at the Court of Domestic Relations, whose philosophy and service is cited in more detail within the body of this chapter. One of the marital partners seeks the services of CDR and is known as the petitioner; his partner assumes the role of respondent. Being involved in marital conflict and, in some instances, being subjected to the authority of the Court to reply to the petition of an alienated marital partner did, in a sense, bring some apathetic, anxious, or angry subjects to the test situation. What errors these feelings introduced into the response to the scale are unknown to us. It should be noted that before the marital partners were seen singly by the interviewer, they were seen jointly by the conciliation counselors, who gave them a brief explanation of our purpose. In every case, one marital partner was seen by the conciliation counselor before responding to our scale. The other partner talked to the counselor after responding to the scale. We recognized but could not control this variable because it would have been an imposition on the Court's clients to keep one waiting while the partner was being tested. We do not know the resultant affect upon a subject's being 
seen prior to or following the interview with the conciliation counselor.

Following the administration of the scale to the subject, the results were recorded on tally sheets containing an assigned number, the role of the participant (husband or wife), and four columns to record how much (completely, a lot, a little, none) he would communicate with his partner about each item.

For the purpose of computation, these items were later transferred to a more concise form, the VA Score Sheet, where weights were assigned to each of the categories: the number three for the response "Completely," two for the response "A Lot," one for the response "A Little," and zero for a "None" response. Total scores of VA of the subject on positive, neutral, and negative items and for the VA he attributed to his partner were compiled on the score sheet. Sample score sheets for one of the couples is shown in Appendix A. Previous discussion under the heading of scale construction explains how the items were designated as positive, neutral, or negative.

The score sheets also contained a column for compilation of the absolute discrepancy between reporting of VA for self and the estimate of VA of the partner. 
Sample

Twenty-three of the twenty-six couples who were administered the VA scale returned a routine questionnaire to CDR providing information regarding the duration of their marriage, the length of separation, their ages, children under eighteen in the home, prior marriage, education, occupation, income, race, religion, and whether or not a divorce had been filed. Some information was omitted from the forms returned, and some appeared to be incorrect. Mention will be made of omissions and suspected errors in information as the categorized information is cited.

Duration of Marriage: Twenty-three couples reported on the longevity of their marriage. The range was from nine months to thirty-five years. Nine of the couples had been married ten years or longer. Of the remaining fourteen reporting couples, nine had been married less than five years, five for from five to ten years. The mean duration of these twenty-three marriages was 10.9 years. Duration of Separation: Five of the twenty-three couples reporting were not separated. One couple had been separated from one to fourteen days; three couples for fifteen to thirty days; eight couples from one to three months; three couples from four to six months; one couple from seven to twelve months. Two of the couples had been separated for over one year. 
Divorce Filed: A divorce had been filed by sixteen of the twenty-two couples reporting on this item. No divorce had been filed in six cases.

Ages: Twenty husbands and a like number of wives reported their ages. The range for husbands was from age twenty to age sixty-two with a mean of 34.8 years. The age range of the wives was from sixteen to sixty-seven years with a mean of 30.9 years. Children under Eighteen: Twenty-two couples reported on children living with them or with one or the other of the separated parents. The total number of children for this group was twentysix for a mean of 1.2 children per family.

Prior Marriages: Three husbands and three wives failed to report on this category. A total number of twenty husbands and twenty wives did complete this item with six husbands and six wives reporting a prior marriage and fourteen of both sexes no prior marriage. Neither of the marital pairs had been married before in eleven instances in which both reported.

Education: Twenty husbands and twenty wives gave their educational backgrounds as follows: Grades one to six, one husband, no wives; grades seven to nine, two husbands, two wives; grades ten to twelve, three husbands, four wives. Seven husbands and eleven wives were high school graduates; two husbands and two wives had one year of college; one husband and one wife had two years of 
college; two husbands had three years of college while two husbands were college graduates. There were no wives in the latter two educational categories.

Employment: Nineteen husbands reported their occupations, and these were categorized as: business, two; professions, two; crafts, five; trades, ten. The sixteen reporting wives were all employed in the trades.

Income: Twenty husbands reported their incomes. Suspected errors in information occurred in this area with two husbands describing their incomes in the 0 to 2,000 dollar bracket and three reporting incomes of $2-4,000$ dollars. These errors may have been attributed to an attempt on the part of the husbands to avoid or lessen support that might be required in the event of final divorce action. There appeared to be no reason to question critically the other reported incomes of five husbands as 4-6,000 dollars. Five had incomes of 6-8,000 dollars; four had incomes of 8-10,000 dollars; one had an income of over 10,000 dollars a year.

Of the fifteen wives who reported their incomes, one was a welfare recipient. Seven wives had incomes of 0-2,000 dollars; two, incomes of 2-4,000 dollars; three, incomes of 4-6,000 dollars; and two had incomes of 6-8,000 dollars. Some of the wives had parttime employment.

Race: Twenty-two of the twenty-three reporting couples were 
white. One inter-racial marriage was recorded.

Religion: Seventeen couples gave complete information regarding this factor. In ten marriages, both partners were Protestant; in two, both were Catholic; in one marriage, both were Jewish. In four marriages, the marital pairs differed in the religious faiths they professed.

Petitioners and Respondents: Fifteen husbands petitioned for the services of the conciliation division of the Court. Thus, they are designated petitioners while their wives as sumed the role of respondents. In the remaining eleven cases, the wives petitioned the Court, placing their husbands in the respondent position. This was the only area in which complete information was available for the twenty-six couples taking part in this study.

\section{The Court of Domestic Relations}

The conciliation services of the Court of Domestic Relations, Multnomah County, Oregon, were established by a 1963 statute authorizing service. The legislation authorizing these services is considered to be the most significant family-law legislation enacted in Oregon in recent years and is designed to provide short-term counseling in a court-supervised environment to prevent, if possible, the finality of divorce. Nationally, the conciliation movement is gathering momentum with a growing number of states enacting 
similar legislation each year. The Oregon statute is modeled after the California statute enacted in 1939. The movement is a positive effort on the part of law and the social work discipline to reduce the rate of marital dissolution and is an expression of the belief that the family is of value and that its integrity should be protected.

Married couples having residence in Multnomah County are eligible for counseling or the conciliation service. The latter service is initiated when one of a marital pair signs and requests filing of a conciliation petition, which then becomes a formal request for service. The petitioner does not need the consent of his spouse, who becomes the respondent once the petition is filed. However, petitions may be jointly filed, and the cooperative approach is highly desirable.

The petition is usually filed following an intake interview with the petitioner. However, petitions are frequently mailed in by a representing attorney. The initial, conjoint appointment is made within two weeks following signing of the petition.

When the jurisdiction of the Court has been invoked by petition, it is the firm policy of the Court that both parties appear. The Court may subpoena a reluctant respondent; but, in practice, this is rarely necessary. A divorce suit need not be on file to use this service.

If either party has filed a divorce complaint and a conciliation petition is subsequently filed, the suit is held in abeyance for a 
45-day conciliation period. If either party files a petition prior to commencement of a suit, both parties are prohibited from filing a suit for 45 days. A petition may, by mutual agreement of the marital pair, be withdrawn; this requires a special order of the Court.

Once the marital pair has appeared for the initial conference, all subsequent sessions are voluntary. If the service is refused at the time of the first appointment, any further use of counseling must be initiated by mutual agreement of the pair.

Traditionally, conciliation courts offer short-term counseling. Couples who need and are willing to accept long-term counseling are referred to accredited community counseling agencies or to those professions (medical) offering more highly specialized services.

Referrals to the conciliation service of this Court come from attorneys, judges, social work agencies, physicians, ministers, teachers, employers, relatives, friends, and self. In 1967, there were 726 conciliation petitions filed in Multnomah County. Reconciliations were effected in approximately one-third of these cases. About one-third of the marital pairs refused reconciliation. The remaining one-third of the couples did not file for divorce but did not continue in the service of the Court. 
CHAPTER IV

\section{RESULTS}

One of the purposes of this study was to develop a scale of verbal accessibility. The scale, as constructed, was based largely upon Goffman's (1959) concept of "impression management" with its descriptive categories of social structure, interaction, and personality. Since these categories were referents for the scale as it was constructed, and since reference is made to them throughout the section on item analysis, a more complete definition of each category follows:

Social structure (S) is concerned with the family as anit and how it is viewed by the public. Cultural expectations and environmental factors play a part as one views such subjects as adequacy of income, money management, status in one's neighborhood, employment, and education.

Interaction's (I) key factor is family role expectation--within and without the marriage--as it relates to self, spouse, children, and relatives. Agreement about child rearing, relationships with in-laws, sexual expectations of marital partners, are examples of this category.

$\underline{\text { Personality }}(P)$ refers to self-concept of a person. Identity, self-confidence, anxiety are reflected in areas having to do with 
physical health or appearance, aspirations, and religious belief.

In order to survey the variable--verbal accessibility--that our scale was planned to measure, we first calculated the median of the responses to each item in order to establish whether the items did range along a continuum from least to most accessible. We chose to use the median rather than the mean as a measure because of the wide dispersion of the scores.

Following calculation of the median measure of accessibility of items, we went on to the development of six unidimensional scales. Five items were included in each scale. Guttman's Scalogram Analysis was used to identify variables occurring along a single qualitative dimension. The literature suggests that "measurements to be meaningful should be along only one dimension at a time" (Stouffer, et al., 1950, p. 46).

In concluding the analysis of the data, we compared various measures of verbal accessibility as related to the reconciliation process (refused or effected) in the testing of the five hypotheses.

\section{Item Analysis}

The first step in analysis of our scale was to find the number of responses to each item in the four categories which were: "completely," "a lot," "a little, " and "none." See Tables XII, XIII and XIV, Appendix B. We computed the medians for the husbands and 
wives separately, using the following formula:

$$
\text { Median }=\text { lower limit of interval }+\left(\frac{\frac{N}{2}-\text { frequency below }}{\text { frequency within }}\right)
$$

We found the interval in which the mid-point (thirteen) of each of the twenty-six respondents fell and used this interval to determine the lower limit of the interval. We applied the formula to each of the fifty-seven usable items.

The median difference of item S 10, shown in Table XI, Appendix $B$, is .00 , indicating that both the husband and the wife responded similarly. Of the remaining fifty-six items, the husbands were more accessible on twenty-seven items, and the wives were more accessible on twenty-nine items. The means of the medians showed no significant difference between the verbal accessibility of the husbands $(\overline{\mathrm{M}}=1.73)$ and that of the wives $(\overline{\mathrm{M}}=1.65)$.

The mean of total VA scores for husbands (98.19) was higher than that for wives $(94.03)$.

The range of total VA scores for husbands was 44 to 167 . The range of total VA scores for wives was 40 to 171 . The total possible range was 0 to 171 . For a comparison of total scores for couples see Table XV, Appendix B.

By comparing the verbal accessibility in the three categories of social structure, interaction, and personality, we found that the wives were the more accessible on the interaction items. They had 
higher median scores than the men in eighteen of the twenty-five items in the interaction category, compared to four of the seventeen items in the structural category and four of the fifteen items in the personality category.

In all three categories, the items with the greatest difference between the median responses of the husbands and wives concerned work roles. The husband was more willing to talk with his wife about "wanting her to work or not to work" (S 17, median 2.50) than the wife was to talk with the husband about "wanting to work or not wanting to work" (median 1.30) with a median difference of 1.20 . The differences between median scores of husbands and wives having to do with working and providing are illustrated by the following items and scores:

$\begin{array}{cc}\text { Median } & \text { Median } \\ \text { Hus- } & \text { Differ- } \\ \text { band Wife } & \text { ence }\end{array}$

S17 Wanting her to work or not to work/wanting to work or not to work

$2.50 \quad 1.30 \quad 1.20$

S 3 Successes in your work

$2.50 \quad 1.70 \quad .80$

S16 Fears you have of losing your job

$\begin{array}{lll}1.21 & .50 \quad .71\end{array}$

I26 Your interest in his/her work

$\begin{array}{lll}1.63 & 2.32 \quad .69\end{array}$

S 9 How your husband/wife handles money

$2.69 \quad 2.17 \quad .52$

S15 Not being able to give him/her everything you would like to

$2.00 \quad 1.50 \quad .50$

P 4 Being unhappy in your job

$1.93 \quad 1.50 \quad .43$




\section{Scalogram Analysis}

Edwards (1957) describes the use of scalogram analysis as it applies in practice as ". . a procedure for evaluating sets of statements or existing scales to determine whether or not they meet the requirements of a particular kind of scale..." (p. 172).

Louis Guttman developed scalogram analysis and

. . considered an area "scalable" if responses to a set of items in that area arranged themselves in certain specified ways. In particular, it must be possible to order items such that, ideally, persons who answer a given question favorably all have higher ranks than persons who answer the same question unfavorably (Stouffer, et al., 1950, p.5).

Thus, a rank ordering of respondents (subjects) and items can provide, without complicated mathematics, a graphic representation of the presence of a scalable area which may or may not be found to satisfy the four criteria described by Green (1954) as:

The reproducibility must be at least . 90 , the item mar ginals must have a large range but must not include extreme values, each response category must have more non-error than error, and errors must be random (p. 363).

Close analysis of the scales indicated that scale patterns in Tables I, III, V, and VI did not meet Green's expectation that there be more non-error than error in each response category. A total of five scale patterns on the se four tables did not meet this requirement. We attribute this to the small sample size.

In order to rank the items and subjects, we assigned the 
weights zero or one to the response categories. The responses "completely" and "a lot" that had had weights of three and two, respectively, were designated as one. The responses of "a little" and "none" that had had weights of one and zero were assigned a zero weight.

The first scale developed utilized personality (P) items responded to by the husband. See Table I. These items formed an

TABLE I

SCALE PATTERNS FOR PERSONALITY ITEMS MEASURING HUSBANDS' SELF-AVOWED FREEDOM TO

COMMUNICATE FEELINGS TO WIVES

\begin{tabular}{|c|c|c|c|c|c|c|c|c|c|c|c|c|}
\hline \multirow{2}{*}{\multicolumn{5}{|c|}{$\begin{array}{c}\text { Patterns Fitting } \\
\text { Item * }\end{array}$}} & \multicolumn{7}{|c|}{ Nonfitting Patterns } & \multirow{3}{*}{$\begin{array}{c}\text { Total } \\
\mathbb{N}\end{array}$} \\
\hline & & & & & \multirow[t]{2}{*}{$\mathrm{N}$} & \multicolumn{5}{|c|}{ Item * } & \multirow[t]{2}{*}{$N$} & \\
\hline 5 & 7 & 6 & 10 & 12 & & 5 & 7 & 6 & 10 & 12 & & \\
\hline+ & + & + & + & + & 3 & + & + & - & + & + & 2 & 5 \\
\hline - & + & + & + & + & 2 & & & & & & & 2 \\
\hline- & - & + & + & + & 6 & & & & & & & 6 \\
\hline - & - & - & + & + & 1 & - & + & - & + & + & 1 & 2 \\
\hline \multirow[t]{2}{*}{-} & - & - & - & + & 5 & + & - & - & - & + & 1 & \\
\hline & & & & & & - & + & - & - & + & 1 & 7 \\
\hline \multirow[t]{5}{*}{-} & - & - & - & - & 1 & + & - & - & - & - & 1 & \\
\hline & & & & & & + & - & + & - & - & 1 & \\
\hline & & & & & & - & - & - & + & - & 1 & 4 \\
\hline & & & & otals & 18 & & & & & Totals & 8 & 26 \\
\hline & Rep & a & bili & $y \quad .94$ & & $\mathrm{Mi}$ & Mra & $\mathrm{Re}$ & rod & cibility & .66 & \\
\hline
\end{tabular}

* Item 5, worries about your health; 7 , fears that you may have a nervous breakdown; 6 , concerns about your appearance; 10 , the way you get along with other people; 12, your hopes for the future. 
acceptable pattern. They seemed referent to the self-concept of the individual who is able to share his aspirations for the future but who becomes more covert when his identity is threatened by a question regarding his appearance or his mental or physical health.

The items that scaled from the least accessible to the most accessible for the husband were:

P 5 Worries about your health

P 7 Fears that you may have a nervous breakdown

$P 6$ Concern about your appearance

Plo The way you get along with other people

P12 Your hopes for the future

Reproducibility was .94. . Minimum reproducibility was .66.

The same technique was used with the personality items in order to develop a similar scale for the wives. See Table II. This scale for the wives reflects an ability to be free to discuss employment identity more than aspects of personal identity such as general abilities, social abilities and health. These items ranged from the least accessible to the most accessible in the following order:

P 5 Worries about your health

Pl0 The way you get along with other people

$P 9$ Feelings that you can't do many things right

Pl2 Your hopes for the future

P 3 Taking pride in doing your job well,

Reproducibility was .93. Minimum reproducibility was .66 . 
TABLE II

SCALE PATTERNS FOR PERSONALITY ITEMS MEASURING WIVES' SELF -AVOWED FREEDOM TO COMMUNICATE FEELINGS TO HUSBANDS

\begin{tabular}{|c|c|c|c|c|c|c|c|c|c|c|c|c|}
\hline \multirow{2}{*}{\multicolumn{5}{|c|}{$\begin{array}{c}\text { Patterns Fitting } \\
\text { Item * }\end{array}$}} & \multicolumn{7}{|c|}{ Nonfitting Patterns } & \multirow{3}{*}{$\begin{array}{c}\text { Total } \\
\mathrm{N}\end{array}$} \\
\hline & & & & & \multirow[t]{2}{*}{$\mathrm{N}$} & \multicolumn{5}{|c|}{ Item * } & \multirow[t]{2}{*}{$\mathrm{N}$} & \\
\hline 5 & 10 & 9 & 12 & 3 & & 5 & 10 & 9 & 12 & 3 & & \\
\hline \multirow[t]{3}{*}{+} & + & + & + & + & 6 & + & + & - & + & + & 1 & \\
\hline & & & & & & + & - & + & + & + & 1 & \\
\hline & & & & & & + & - & + & + & - & 1 & 9 \\
\hline \multirow[t]{2}{*}{-} & + & + & + & + & 3 & - & + & - & + & + & 1 & \\
\hline & & & & & & - & + & + & - & - & 1 & 5 \\
\hline- & - & + & + & + & 3 & - & - & + & - & + & 1 & 4 \\
\hline- & - & - & + & + & 3 & - & - & - & + & - & 1 & 4 \\
\hline- & - & - & - & + & 2 & & & & & & & 2 \\
\hline \multirow[t]{3}{*}{ - } & - & - & - & - & 2 & & & & & & & 2 \\
\hline & & & & tals & 19 & & & & & Totals & 7 & 26 \\
\hline & $\overline{R e p r}$ & duc & bilit & .93 & & $\mathrm{Mi}$ & mur & -0 & roc & cibility & .66 & \\
\hline
\end{tabular}

* Item 5, worries about your health; 10, the way you get along with other people; 9, feelings you can't do many things right; 12, your hopes for the future; 3 , taking pride in doing your job well.

In examining the most and least accessible items on the scale of personality items, we found that both husband and wife were least accessible regarding:

P 5 Worries about your health.

The following item was most accessible for husbands and second most accessible for wives: 
P12 Your hopes for the future.

The low accessibility of the item about health may be viewed as denial of a threat to personal competance and/or identity. In speculating about the attitudes of the subjects, it seems that while "hopes for the future" might be a "safe" subject, it may also hold the expectation of something better after either counseling or divorce.

Those items with higher verbal accessibility are those having positive connotations, and those items with low verbal accessibility, negative connotations.

Another explanation worth considering is that least accessible item s are more specific; most accessible items have more ambiguous referents. The implications of this explanation might be that the most ambiguous items are less likely to secure valid responses.

Separate scales were devised for husbands and wives using interaction items. See Tables III and IV. The items which scaled are shown below for the husbands, from the least accessible to the most accessible.

I 4 Her hurting your parents' feelings

I21 Her demands for sex relations too often

Il 6 Her demanding too much of your time

I 9 Her criticizing you in front of the children

I 8 Her ways of disciplining the children

For the wife:

I2 1 His demands for sex relations too often 
TABLE III

SCALE PATTERNS FOR INTERACTION ITEMS MEASURING HUSBANDS' SELF-AVOWED FREEDOM TO

COMMUNICATE FEELINGS TO WIVES

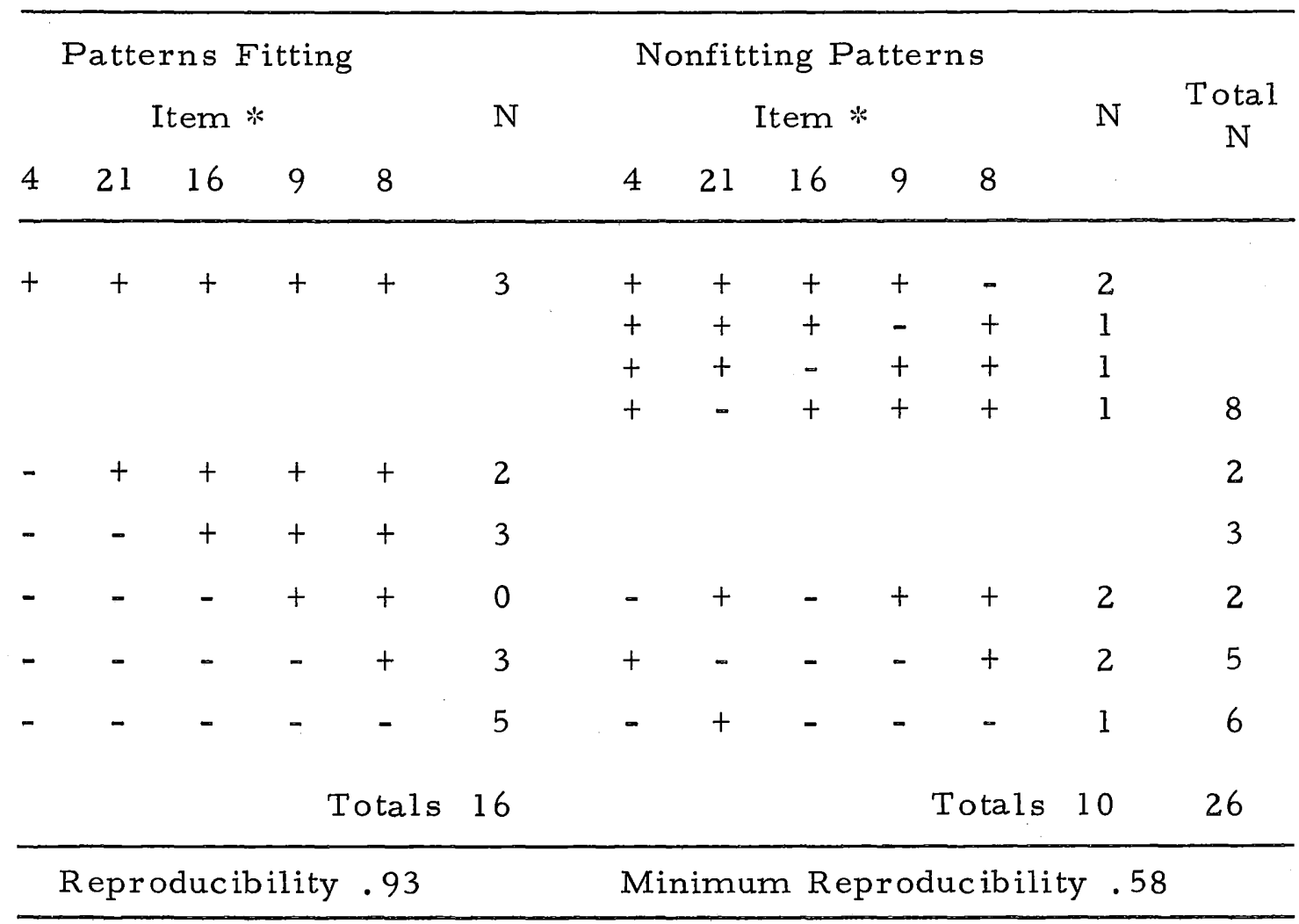

* Item 4, her hurting your parents' feelings; 21, her demands for sex relations too often; 16, her demanding too much of your time; 9 , her criticizing you in front of the children; 8 , her ways of disciplining the children.

Il 6 His demanding too much of your time

Il 0 His expecting too much of the children

I 9 His criticizing you in front of the children

I 8 His way of disciplining the children

For the husbands' scale, reproducibility was .93 and minimum reproducibility was $: 58$. For the wives' scale, reproducibility was .94 and minimum reproducibility was .62 . 
TABLE IV

SCALE PATTERNS FOR INTERACTION ITEMS MEASURING WIVES' SELF-AVOWED FREEDOM TO COMMUNICATE FEELINGS TO HUSBANDS

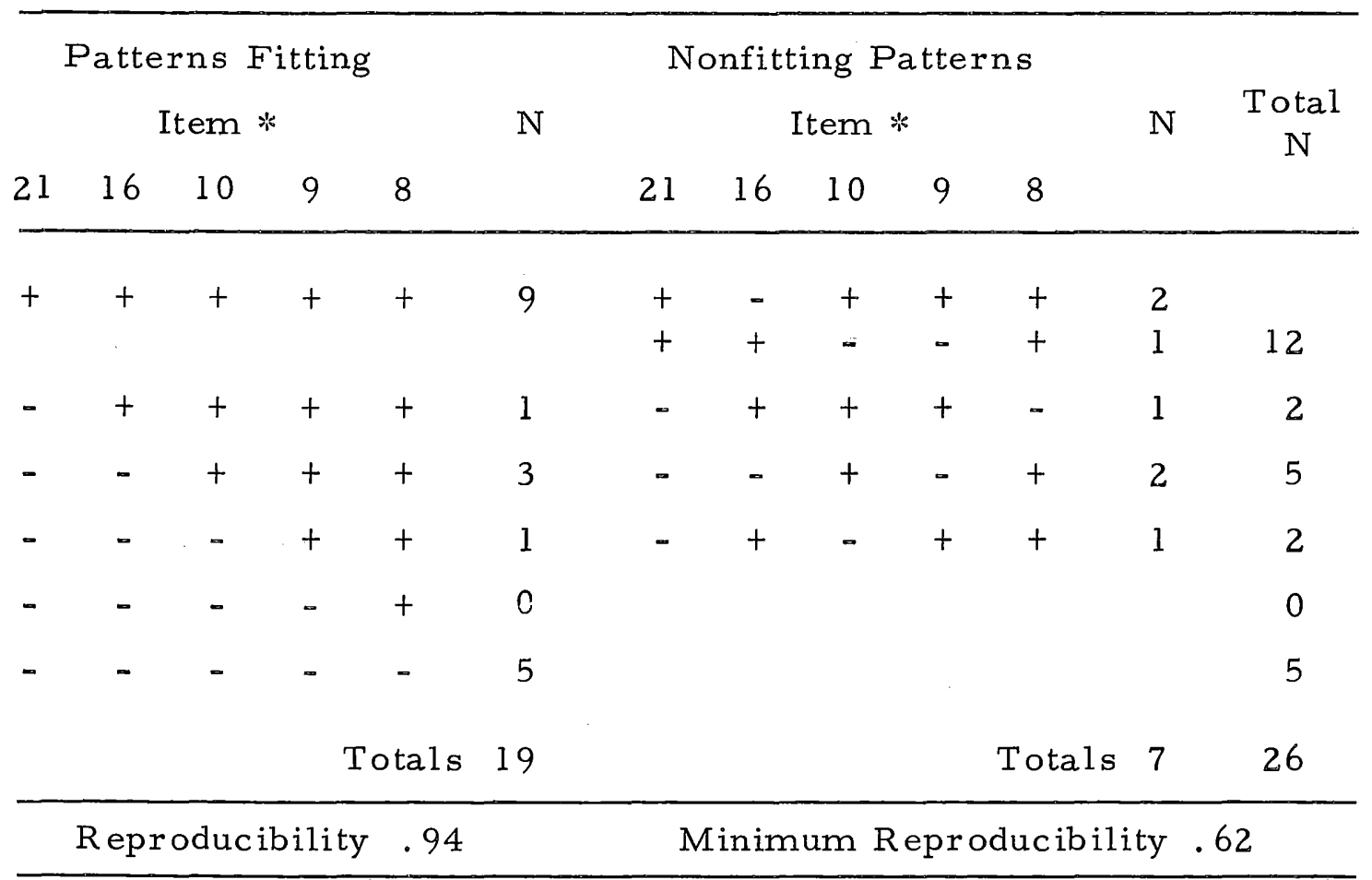

* Item 21, his demands for sex relations too often; 16, his demanding too much of your time; 10 , his expecting too much of the children; 9, his criticizing you in front of the children; 8 , his way of disciplining the children,

In looking at the interaction items, we speculated that it is easier to be more verbal about things which are removed from the self and are situational or reality bound. For example, there was high verbal accessibility for husbands in the area of "her ways of disciplining children" (situational bound and arising out of observed behavior) and low verbal accessibility in response to "hurting your parents' feelings." The latter may reflect protectiveness toward 
parents as it might be related to protectiveness of one's ego ideal and ego identity with parental figures.

Social situations regulate and demand verbal responses to problems which are visible; greater verbal accessibility is thus often inescapable. In the intimate and less visible areas of one's life, there is less outside pressure to acknowledge problems. Such areas may be protected from exposure. Thus, problems which might be damaging to the ego will be the last to be dealt with, and least accessible.

Two additional scales were devised, combining personality and interaction items from each of the aforementioned scales. For both the husbands and wives we chose three interaction and two personality items. See Tables V and VI. The scaled items for the husbands ranked in the following order from the least accessible to the most accessible:

P 5 Worries about your health

I 4 Her hurting your parents' feelings

I21 Her demands for sex relations too often

Pl0 The way you get along with other people

I 7 Her lack of interest in the children

Reproducibility was .93. Minimum reproducibility was .66 .

The scale for the wife ascends from low to high verbal accessibility in the following order: 
TABLE V

SCALE PATTERNS FOR COMBINED INTERACTION AND

PERSONALITY ITEMS MEASURING HUSBANDS'

SELF-AVOWED FREEDOM TO COMMUNICATE

FEELINGS TO WIVES

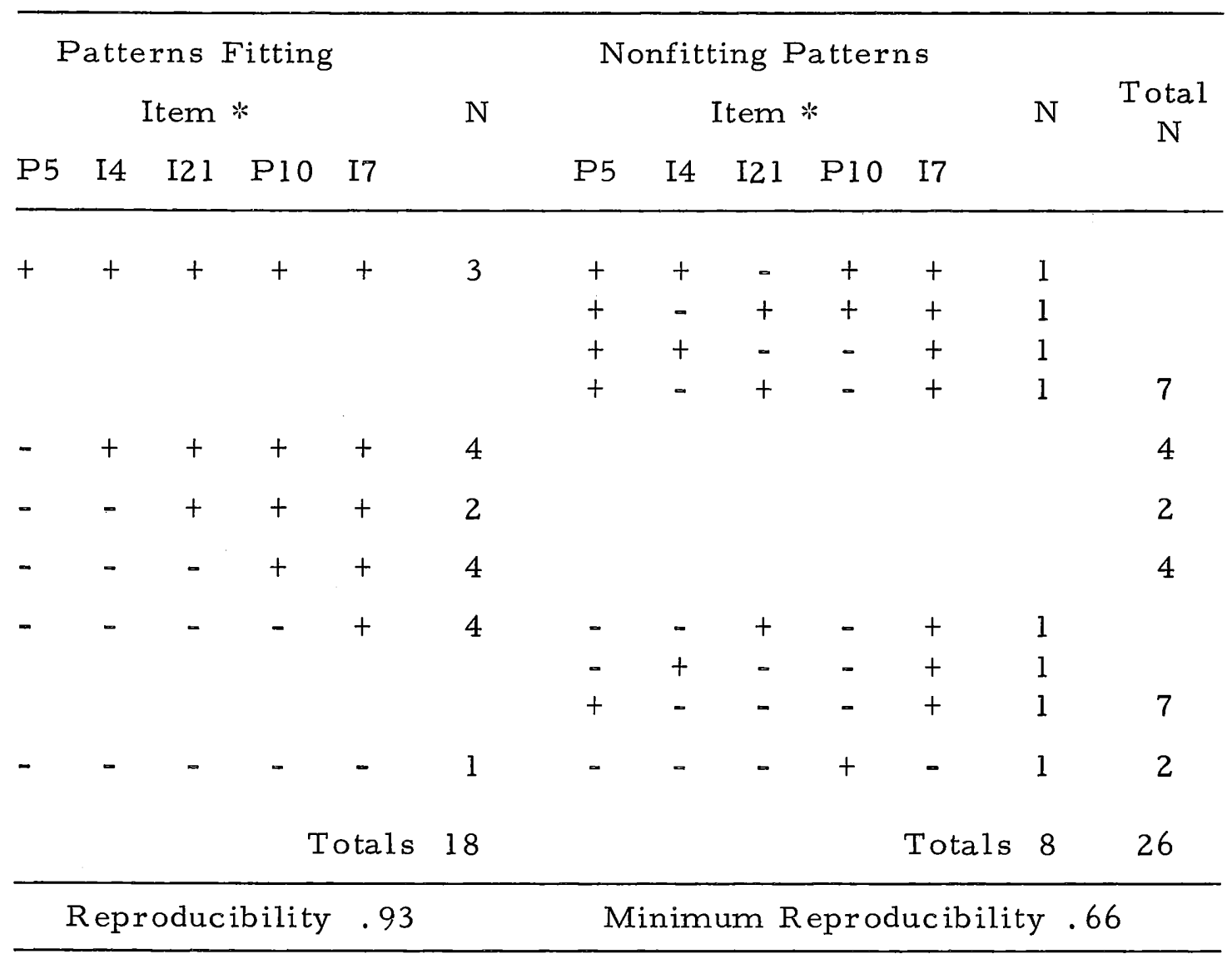

* Item P5, worries about your health; I4, her hurting your parents' feelings; I2l, her demands for sex relations too often; P10, the way you get along with other people; I7, her lack of interest in the children.

$P 5$ Worries about your health

I 21 His demands for sex relations too often

P16 Things about yourself that you dislike or are a shamed of

I 9 His criticizing you in front of the children

I $8 \mathrm{His}$ way of disciplining the children 
TABLE VI

SCALE PATTERNS FOR COMBINED INTERACTION AND

PERSONALITY ITEMS MEASURING WIVES' SELF-

AVOWED FREEDOM TO COMMUNICATE

FEELINGS TO HUSBANDS

\begin{tabular}{|c|c|c|c|c|c|c|c|c|c|c|c|c|}
\hline \multirow{2}{*}{\multicolumn{5}{|c|}{$\begin{array}{c}\text { Patterns Fitting } \\
\text { Item } *\end{array}$}} & \multicolumn{7}{|c|}{ Nonfitting Patterns } & \multirow{3}{*}{$\begin{array}{c}\text { Total } \\
\mathrm{N}\end{array}$} \\
\hline & & & & & \multirow[t]{2}{*}{$\mathrm{N}$} & \multicolumn{5}{|c|}{ Item * } & \multirow[t]{2}{*}{$\mathrm{N}$} & \\
\hline P5 & I2 1 & P16 & I9 & I8 & & $\mathrm{P} 5$ & I21 & $\mathrm{P} 16$ & I9 & I8 & & \\
\hline \multirow[t]{2}{*}{+} & + & + & + & + & 5 & + & + & + & - & + & 1 & \\
\hline & & & & & & + & - & + & + & + & 2 & 8 \\
\hline- & + & + & + & + & 3 & & & & & & & 3 \\
\hline - & - & + & + & + & 0 & & & & & & & 0 \\
\hline \multirow[t]{2}{*}{-} & - & - & + & + & 3 & - & + & - & + & + & 3 & \\
\hline & & & & & & + & - & - & + & + & 1 & 7 \\
\hline - & - & - & - & + & 2 & & & & & & & 2 \\
\hline \multirow[t]{3}{*}{-} & - & - & - & - & 4 & - & $=$ & - & + & - & 1 & \\
\hline & & & & & & - & - & + & - & $=$ & 1 & 6 \\
\hline & & & & otals & 17 & & & & & Totals & 9 & 26 \\
\hline & Repr & duc & lit & .96 & & & air & $\mathrm{n}$ & $P$ & acib & ty & \\
\hline
\end{tabular}

* Item P5, worries about your health; I21, his demands for sex relations too often; P16, things about yourself that you dislike or are ashamed of; I9, his criticizing you in front of the children; I8, his way of disciplining the children.

Reproducibility was .96. Minimum reproducibility was .66 .

We found that both the husband and the wife were relatively inaccessible about the partner's too frequent demands for sex relations. Both were least accessible about matters of health and most accessible about each other's handling of the children. This 
combined scale may reflect the tendency of husbands and wives to be protective of selves when a potential threat to self esteem is involved. Situations that are more visible to the public or publics of a marital pair, or more removed from the realm of the personal, are most accessible on these scales for husbands and wives.

\section{Hypothesis Testing}

In our sample of twenty-six couples, there were nine in which a reconciliation was effected and twelve in which a reconciliation was refused. Five of the couples neither filed for divorce nor returned for conciliation services. These couples were designated as "off schedule" (OS) and were not included in the statistical tests of the hypotheses.

Differences between RE (reconciliation effected) means and RR (reconciliation refused) means were tested for statistical significance by using $\underline{t}$-tests. A $\underline{t}$-test had to attain a value of 2.093 to indicate statistical probability of .05 or better. None of the t-tests were statistically significant. See Tables VII, VIII, IX, and X for the results of the hypothesis testing.

Hypothesis I stated that 'The more similar marital partners' verbal accessibility, the greater the likelihood of reconciliation." To test this hypothesis, each husband and each wife's total VA score (on all 57 items) were compared. The difference between husband 
and wive's total VA scores was used as a measure of the actual similarity of VA. The nine couples who refused reconciliation had a mean similarity score of 38.08 . The twelve couples who effected reconciliation had a mean similarity score of 49.44 . The difference between these means was not found to be significant by $\underline{t}$-test. Thus, the hypothesis was not confirmed. See Table VII.

TABLE VII
RELATIONSHIP: BETWEEN RECONCILIATION AND ACTUAL SIMILARITY OF MARITAL PARTNERS' VERBAL ACCESSIBILITY

\begin{tabular}{lcccc}
\hline & \multicolumn{3}{c}{ Actual similarity of marital partners' } \\
& Mean & Variance & $\begin{array}{c}\text { Standard } \\
\text { Deviation }\end{array}$ & t* \\
\hline Refused & 38.08 & 494.17 & 22.2 & .80 \\
Effected & 49.44 & 1431.02 & 37.08 & .80 \\
\hline
\end{tabular}

* A t-value of 2.093 is significant at the .05 level of probability. The difference between the means is not statistically significant.

Hypothesis II stated that 'The greater the marital partners' assumed similarity of verbal accessibility, the greater the likelihood of reconciliation." Assumed similarity is the degree to which an individual believes that another person is similar to him. We measured assumed similarity for the husband by comparing his responses for himself with the responses he attributed to his wife. 
The wife's assumed similarity was measured in the same way.

To obtain the mean for hypothesis II, we compared the husband's score for self on each item with the score he would assign to his wife as to how much she would talk to him about the same subject. We summed the item discrepancy scores for the husbands, dividing by $N(9)$ for $R R$ 's to obtain a mean score of 55.50 , and by $N(12)$ for RE's to obtain a mean score of 47.44 . Similar procedures were used for the wives, which resulted in a $R R$ mean of 60.23 and a RE mean of 44.00 . The difference between the means was not found to be significant by $\underline{t}$-test for either husbands or wives. Thus the hypothesis was not confirmed. See Table VIII for the husbands and IX for the wives.

TABLE VIII

RELATIONSHIPS BETWEEN RECONCILIATION AND VERBAL ACCESSIBILITY MEASURES FOR HUSBANDS

\begin{tabular}{lllrrr}
\hline $\begin{array}{l}\text { Measures } \\
\text { of Verbal } \\
\text { Accessibility }\end{array}$ & $\begin{array}{c}\text { Reconcili- } \\
\text { ation }\end{array}$ & Mean & Variance & $\begin{array}{c}\text { Standard } \\
\text { Deviation }\end{array}$ & t * \\
\hline II. Assumed & Refused & 55.50 & 343.36 & 18.5 & .98 \\
Similarity & Effected & 47.44 & 342.27 & 18.5 & .85 \\
III. Positive & Refused & 19.75 & 39.17 & 6.30 & .85 \\
& Effected & 17.55 & 30.52 & 5.52 & \\
IV. Negative & Refused & 62.83 & 417.24 & 20.4 & 1.39 \\
& Effected & 50.77 & 360.19 & 19.0 & \\
\hline
\end{tabular}

* A t-value of 2.093 is significant at the .05 level of probability. Since all of the values fell below this, none of the differences between means are statistically significant. 
TABLE IX

RELATIONSHIPS BETWEEN RECONCILIATION AND VERBAL ACCESSIBILITY MEASURES FOR WIVES

\begin{tabular}{|c|c|c|c|c|c|}
\hline $\begin{array}{c}\text { Measures } \\
\text { of Verbal } \\
\text { Accessibility }\end{array}$ & $\begin{array}{l}\text { Reconcili- } \\
\text { ation }\end{array}$ & Mean & Variance & $\begin{array}{l}\text { Standard } \\
\text { Deviation }\end{array}$ & $t *$ \\
\hline $\begin{array}{l}\text { II. As sumed } \\
\text { Similarity }\end{array}$ & $\begin{array}{l}\text { Refused } \\
\text { Effected }\end{array}$ & $\begin{array}{l}60.23 \\
44.00\end{array}$ & $\begin{array}{l}526.24 \\
429.00\end{array}$ & $\begin{array}{l}22.9 \\
20.7\end{array}$ & 1.69 \\
\hline III. Positive & $\begin{array}{l}\text { Refused } \\
\text { Effected }\end{array}$ & $\begin{array}{l}18.41 \\
19.22\end{array}$ & $\begin{array}{l}28.74 \\
93.40\end{array}$ & $\begin{array}{l}5.4 \\
9.6\end{array}$ & .22 \\
\hline IV. Negative & $\begin{array}{l}\text { Refused } \\
\text { Effected }\end{array}$ & $\begin{array}{l}60.33 \\
61.33\end{array}$ & $\begin{array}{r}446.24 \\
1326.00\end{array}$ & $\begin{array}{l}21.12 \\
36.43\end{array}$ & .07 \\
\hline
\end{tabular}

* A t-value of 2.093 is significant at the .05 level of probability. Since $\bar{e}$ all of the values fell below this, none of the differences between means are statistically significant.

Hypothesis III stated that "The higher the verbal accessibility on positive items, the greater the likelihood of reconciliation." To obtain a measure of VA on positive items, we summed an individual's responses to the ten positive items. The means of the scores for the 9. RE husbands was found to be 17.55. The scores of the $12 \mathrm{RR}$ husbands had a mean of 19.75 . The same procedure was used to find the means of wives' scores on positive items, and yielded a mean of 19.22 for $R E$ wives and a mean of 18.41 for $R R$ wives. The difference between the means of the husbands or the wives did not prove to be significant by $\underline{t}$-test and the hypothesis was not confirmed. 
See Table VIII for the husbands, and IX for the wives.

Hypothesis IV stated that "The higher the verbal accessibility on negative items, the less the likelihood of reconciliation." To obtain a measure of VA on negative items, we summed the individual's responses to the forty negative items. The means of the scores for the $9 \mathrm{RE}$ husbands was found to be 50.77. The scores of the $12 \mathrm{RR}$ husbands had a mean of 62.83 .

The procedure was repeated for wives, yielding a mean of 61.33 for $R E$ wives and a mean of 60.33 for $R R$ wives. The differ ence between the means of husbands and the wives did not prove to be significant by $\underline{t}$-test, and the hypothesis was not confirmed. See Table VIII for the husbands and IX for the wives.

Hypothesis V stated that "The higher the verbal accessibility of the respondent on positive and neutral items, the greater the likelihood of reconciliation."

To obtain a measure of VA on positive and neutral items, we summed the responses of the respondents to those seventeen items (ten positive items and seven neutral items). Of the ten husband respondents, five reconciled. Of the eleven wife respondents, four reconciled. The mean of the scores of the nine RE respondents was 22.22. The mean of the scores of the twelve $R R$ respondents was 30.58. The difference between the means was 1.88 and proved to be significant by use of a one-tailed test (at the .05 level of probability, 
1.73 is significant with 19 degrees of freedom). However, since the hypothesis proved significant opposite to the direction predicted the use of a two tailed test was required. A two-tailed test at the .05 level of probability would be significant at 2.093 . Thus, the differ ence between the means was not statistically significant. See Table X.

All of the hypotheses were aimed at testing the relationship between marital partners' verbal accessibility and reconciliation. The fact that our t-values were not statistically significant may well have been due to the small sample size.

TABLE X

RELATIONSHIP BETWEEN. RECONCILIATION AND VERBAL ACCESSIBILITY ON POSITIVE AND NEUTRAL ITEM MEASURES FOR RESPONDENTS

\begin{tabular}{llccc}
\hline $\begin{array}{c}\text { Reconcili- } \\
\text { ation }\end{array}$ & Mean & Variance & $\begin{array}{c}\text { Standard } \\
\text { Deviation }\end{array}$ & t* \\
\hline Refused & 30.58 & 98.62 & 9.93 & \\
Effected & 22.22 & 95.19 & 9.76 & 1.88 \\
\hline
\end{tabular}

* A t-value of 2.093 is significant at the .05 level of probability. The difference between the means is not statistically significant. 
CHAPTER V

\section{CONCLUSIONS}

\section{Findings}

Most research in VA has focused on the therapeutic dyad. Our present study has applied the concept of VA to an investigation of self-reported communication between marital pairs. The basic notion underlying our research was that there is a correlation between high VA and the healthy personality, and further, that high VA was representative of problem solving ability. We hypothesized in the direction of a greater likelihood of reconciliation if VA scores were similar, high on positive and neutral items, and low on negative items. We must conclude from our study that there is no essential difference in self-reported VA level between reconciled and unreconciled marital partners. The overall differences in VA levels between men and women are interestingly in the direction of higher VA scores for the male subjects. This result, although not statistically significant, is at odds with previous research in this area which indicates greater verbal productivity in the female (Levinger and Senn, n.d.). In the present study, the mean of the median responses for husbands (1.73) was higher than that of wives (1.65), and the mean total VA score of husbands $(98.19)$ was higher than that 
of wives (94.03). Since it is a commonly accepted notion that women reveal more than men, we have assumed that this finding is not exclusively a sex-linked characteristic.

One posible explanation is that our sample is not representative of the general population. Counselors at the Court characterize their clients as having a great deal of "pathology." We suggest then that our sample might have low empirical VA of the person, or possibly a distorted sense of what verbal communication means. Another factor possibly affecting our results is the preponderance of negative items used in our study. High negative verbal interaction might be expected between pre-divorce marital pairs and reflect attitudes about the situation of the divorce proceedings rather than attitudes about the marital relationship. The latter seems to have more importance for reconciliation (Karr, 1966) than the former (Bernard, 1964, p. 688). Our negative findings suggest that high verbal accessibility, in and of itself, is not as important as we initially believed.

We know also that the Court receives more petitions from husbands than from wives, and that our sample had more husband petitioners than wife petitioners. The petitioner is the person who requests conciliation service and so in most cases might be more motivated to save the marriage. "The point has been made that the person who comes to the counselor for help in a marital situation is 
usually the one on whom the weight of adjustment ultimately falls" (Bernard, p. 681). This motivation may have served to stimulate either actual or reported verbal communication. Therefore, the Court situation in itself may account for the higher reported VA of the husbands.

Although the mean of median responses of husbands was slightly higher than wives (See Table XI, Appendix B), wives' scores for interaction items were somewhat higher than husbands. This may be explained as a result of the woman's greater concern about relationships in the family. It may also suggest that as our culture moves away from clear cut role definitions, such as exist in a traditional marriage, role changes bring accompanying uncertainty. In her attempt to stabilize the marriage, the wife may be forced to become more aggressive verbally in an effort to better define roles. This could explain the wives' relatively greater VA about interactional matters.

An alternate explanation may be found in the nature of inter action items. These items appear bound in observed or perceived behavior and expectation and are a reflection of the nature of the relationship. Due to the greater specificity of these items, they may more adequately tap into determinant attitudes and thus be a better measure of VA than the more ambiguous items.

We hypothesized that $\mathrm{RE}$ respondents would have higher positive 
verbal accessibility on positive and neutral items than RR respondents. This hypothesis was derived from the assumption that the petitioner is motivated to maintain the relationship, and therefore that the respondent's attitude toward the marriage would determine the continuance of the marriage.

Contrary to our hypothesis, the results show that RR respondents had a higher mean of verbal accessibility on positive and neutral items, than did $R E$ respondents.

We speculated about the meaning of these results. They seem to suggest that the respondent was trying to create an impression of cooperation. That is, the respondent, having made up his mind to obtain a divorce, may have reported spuriously high accessibility in order to avoid blame, and involvement in counseling. Another possible explanation of the finding is that a satisfactory marriage and an $\mathrm{RE}$ outcome of conciliation services requires one partner with high verbal accessibility and one partner with low verbal accessibility. This latter speculation is even more difficult to substantiate, however.

\section{Limitations of Present Study}

As stated previously, this study was designed to develop a scale which would permit examination of the verbal accessibility of attitudes relevant for marriage, and also to measure the VA of 
individuals. In regard to development of the scale, we were partially successful. Items reflecting attitudes about sex were found to have low accessibility as were items reflecting attitudes about poor health. Because reported VA was generally higher in other areas, we con-' clude that some items in our scale differentiated more accessible attitudes, such as children and employment, from less accessible attitudes, such as sex and health concerns. Therefore, this scale, with further refinement, appears to have potential for examination of verbal accessibility of attitudes relevant for marriage.

The breakdown of items into social structure, interaction and personality categories was subjective and based on a priori considerations. We later found these categories of little use because the items could not be empirically categorized by this scheme. If such a breakdown is used in the future, we suggest that the items be rated independently by category. Such a rating might permit testing of the idea that verbal accessibility decreases around areas or items as they become more ego-threatening.

We do not believe that the scores we found for individuals, however, were really measurements of verbal accessibility. VA of the person is thought to be a relatively stable and enduring characteristic, subject to situational flux. We suspect that because of the situational stress and anxiety inherent in the Court setting that VA was artificially stimulated, or even depressed in some cases. Our 
scores do not reflect VA of the person, or even VA of the attitude as conceptualized by Polansky (1965), but rather they reflect VA in one particular situation. Situational VA cannot be generalized to VA of the person; we have no measurement of the stable and enduring VA of the person.

The scores we obtained were influenced by an undetermined amount of response bias. The situation in which the questionnaire was administered probably inhibited and distorted the couples understanding of the instructions. Many also had difficulty with the question stem "would you talk . . " If the couple had been separated for some time, or if they could remember more pleasant times, they became confused about the time period we wished to investigate. They frequently based their answers on previous experience. If they had no experience with a particular question, such as difficulty with in-laws, their response was that they would not talk at all. They were unable to project themselves, or detach themselves from the immediate stimuli. Since the prospect of divorce pushes the concept of the spouse to an extreme, we suspect that there was also some distortion and perseveration of responses.

There was some unevenness of presentation of the research project to the couples by the Court. There was probably some interviewer bias present also, for which we cannot account. The instructions presented by the interviewers were subject to individual 
differences in emphasis and explanation, and all but one of the couples were interviewed by female interviewers. The effect of this is undetermined.

We also raise the question as to the adequacy of self reporting in determination of verbal accessibility. Perhaps some observational data and reports of significant persons such as Polansky uses might be more useful in determining VA.

Another objective of this study was to determine the relationship between self-reported VA and reconciliation of marital partners. The dependent variable of reconciliation weakened our hypothesis testing because we do not really know what reconciliation means for marital interaction. It can have many social, and personal variables (Levinger, 1965). This weakness perhaps could have been partially avoided by having the counselors rate the desirability of reconciliation. A scale of marital satisfaction could also have been administered. Couples might also be asked to rate the reasons for reconciliation. This would be an aid in determining what barriers were operating to retard dissolution of the marriage. Verbal accessibility is not the only variable affecting reconciliation, and narrow reliance on it as the independent variable in hypothesis testing tends to be self-defeating.

Another fact is that verbal accessibility is a complex characteristic. It is a reflection of personality organization and ego strength. 
VA also has socio-cultural components of undetermined influence. It is affected by such variables as sex, education, religion and socioeconomic class. VA about marriage would also be related to the socio-cultural and individual attitudes and expectations about marriage.

In addition to the se methodological weaknesses in our study, our sample size was a limiting factor. A larger sample would have made our hypothesis testing and findings more conclusive, one way or the other. With a larger sample we could have controlled such variables as length of separation, years of marriage, religion, socio-economic class, etc. A larger sample would also have permitted comparison of VA scores between male and female respondents, male and female petitioners, male respondents and petitioners, and female respondents and petitioners. It would have been of value to have a "normal" sample for purposes of comparison. Differences would probably be found in attitude areas between intact marriages and pre-divorce marriages. If a measure of VA of the person could be found for both samples, we would predict that pre-divorce couples would have generally lower VA of the person than couples in intact marriages.

As noted above we took a calculated risk by relating all of our hypotheses to a single variable--reconciliation. We took the not uncommon position that refraining from divorce is a criterion of 
marital success. We further assumed that there was a high probability of finding a measurable difference in VA between the RE couples and RR couples. This is the implicit criterion in studies which use divorced persons as controls. The conciliation service is geared to this idea and periodically reports success statistically in the numbers of RE's and, failures in RR's. Counselors typically rate RE's and RR's with more sensitive criteria. In many cases they realize that $\mathrm{RE}$ is obtained only because the offended mate agrees to continue to "put up" with the offending behavior of the other, e.g., drinking, infidelity, excessive spending, and the like. It would appear that the principle of least interest applied here, that the one who cares more about preserving the relationship is at a distinct disadvantage vis-a-vis the one who cares less (Ross, 1921 , p. 136). The person who cannot tolerate strife will give in to the person who can. We can conclude that exploitation is inherent in a relationship which one person values more than the other. The mixed motive theme (Bernard, 1964, p. 700) is a dimension along which our sample could have been measured and would seem to have research implications.

As a result of meetings and discussions between the research team and the professional conciliation staff, we are able to make a few generalizations concerning our sample. The concept of marriage counseling "by legal force" is relatively new and introduces variables 
not yet thoroughly understood or appreciated. There are some notable differences, however, between conciliation clientele and clientele served by voluntary agencies and private practitioners. There is a high incidence of individual pathology and of bizarre interactional strategies among the former. The statistical period for the conciliation agency reporting is based on the 45-day divorce moratorium, and there have been as many as three to four commitments to mental institutions reported during such periods. Official records of the Court are beginning to reveal a significantly greater number of suicides than are seen in voluntary agencies. There are at least two questions raised. Does an authoritative agency such as the conciliation service reach a unique sector of marriages not ordinarily exposed to counseling services, or is the conciliation service reaching essentially the same kinds of marriages but at a different time in the development of marital trouble? The answer to both questions appears to be "yes."

Our sample is described in Chapter III and much of the se data heavily under score the previously discussed idea that the conciliation service is reaching a unique sector of marriages. This sector differs significantly from the pre-divorce marriages seen in voluntary settings. Most worthy of note are the facts that only 5 coúples of our reporting sample were not separated; at least 16 divorces had already been filed and divorce was an explicit is sue in the entire 
sample. Even the most optimistic therapist would be forced to admit that the majority of these marriages were well past the optimal time for reversing the destructive alienation spiral. It is indeed remarkable that therapeutic intervention prevented divorce as outcome for nine of these couples, with possibly more reconciliations concealed in the five off-schedule cases.

Divorce as strategy and process (Bernard, 1964, p. 723) appears to be a characteristic of our sample. The best empirical data on the divorcing process is that of Goode (1956). In reference to women only, he found that there was a twelve-month elapsed time between the first serious consideration of divorce and the actual filing of the suit.

Since the basic theme of the divorce strategy is one of attempting to gain a favorable legal position, we suggest that self-reported VA scores are skewed by this variable. In fact, there are an undetermined number of cases in which the attorneys advise their clients to file a conciliation petition to 1) make the client look better in court and 2) give the attorney and his client the necessary time to prepare a strong case. Therefore, even though a reconciliation may be effected, frequently the initial filing is based on motivations of selfinterest. Our study was focused on the beginning of the conciliation process and presumably tapped attitudes affected by the strategic considerations in the divorce process. 
We believe that the marriages included in the present sample are analogous to the "hard to reach" client, and, are in fact, hard to reach marital relationships, within which we would expect to find a relatively high frequency of psychological problems at the personality disturbance or character disorder end of the spectrum. Reiner and Kaufman (1959) reason to this same conclusion when they say:

We found, in classifying the cases studied in the juvenile delinquency research unit, - - that a majority of the parents fell into the category of impulse-ridden character disorders. It seems likely that a relatively high proportion of adults under the care of other agencies also belong in this category. The proportion is doubtless highest in agencies dealing with delinquents and hard to reach families . . It is probably safe to say that families with members suffering from severe character disorders represent the most serious social problem in our country (pp. 3-4).*

For these reasons we believe that our sample was significantly weighted by the character disordered person. This variable has profound implications for our study since ". . . the se acting-out persons--in spite of the intensity of their emotions--cannot enter into a discussion of their feelings and behavior. Their way of communicating is through actions" (p. 4).*

What, then, can we make of the relatively high reported VA of our Court sample? There are at least three possible answers: 1) In our total sample of 26 couples, conflict had already been explicitly 
escalated into divorce strategy. In the adversary system of divorce litigation the case is "won"' by the spouse who can show "clean hands." The conciliation service is an arm of the Court and, therefore, the clients will tend to show themselves advantageously by reporting a willingness to communicate. 2) The authoritarian setting with its subjectively felt threat can be rendered less dangerous by reporting "good behavior," i.e., willingness to communicate, and 3) the responses of the subjects to the VA items could have been aspirational, i. e., "this is the way I wish it could have been" or, "this is the way I want it to be in the future." We suggest that the reported VA of our sample was in reality an attempt on the part of the reporting subjects to extricate themselves psychologically from a subjectively difficult situation by meeting perceived cultural expectations. We, therefore, conclude that this sample is not representative of a general population of pre-divorce couples. Further, marriage appears to be too complicated to study with only two variables. While social work practitioners often place great emphasis on the value of communication in marriage, it becomes apparent that there are often other factors relevant to maintenance of a marital relationship. We also feel that more than one measure of output or communication, and some indication of personality organization is necessary for a valid measure of verbal accessibility. In other words, a 
measure of VA of the person must be a measure of how accessible a person is in a representative group of situations.

\section{The Study of Marriage and Divorce}

Stryker (1964) noted "Marriage in American society is becoming defined as an exclusively erotic relationship and, consequently, is inherently unstable" (p. 147). He reasons that divorce is the end product of a process of alienation.

- . alienation--rests on a series of crises. Typically, there occurs early in the process a disturbance of erotic relationships arising out of a lack of rapport. Then, what may have been privately considered becomes a matter of public definition through the overt mention of the possibility of divorce (p. 147).

The therapeutic response to relationship crises in marriage and research efforts related to these crises have, therefore, focused sharply on problems of communication. It is interesting to note that paralleling the pragmatic exploration of communication in marriage, there has been expressed a more general interest in communication between human beings, unimpeded by things or objects. Buber (1958) holds such communication to be the ideal in human relationships and refer to it as the I-Thou relationship.

Marriage has been studied by a variety of approaches, ranging from the traditional institutional or structural-functional to the contemporary interactional. The basic feature of the interactional study 
of marriage is communication. A tendency exists within popular and professional literature to enthrone communication. This trend has arisen from the historically changing nature of the institution of marriage, and the increasing demands which have been made upon marital partners for companionship marriages, that stress the necessity for an enjoyable relationship and maintenance of a high degree of active communication.

The institutional marriage is characterized by traditional orientation and parallel patterns of behavior in which husband-wife role definitions are sharply drawn. Each lives his or her life primarily in a male or a female world (Bernard, 1964).

In the companionship marriage much greater demands are placed on the marital relationship for personal involvement. The interactional emphasis in contemporary marriage places high value on personality involvement and, therefore, high value on phenomena which enhance interaction. Factors inimical to fulfilling relationships are seen as undesirable. Communication, verbal and nonverbal, is the all inclusive term which describes the reciprocal behavior in the interactional marital relationship.

As noted earlier, reciprocity in the traditional marriage is primarily restricted toward mutual performance of roles. Personal unhappiness in relationships in such marriages typically is an accepted fact of life. A total failure in the institutional family, 
results from failures in role performance, and is, therefore, almost completely on public view. Failures in the companionship marriages, however, are frequently highly invisible to the community. Adequate role performance (the publicly visible aspects) may persist for some time, in spite of increasing dysfunctions in more intimate aspects of marital interaction. Hence, the frequent expressions of surprise among friends and acquaintances when the divorce announcement takes place.

Divorce was a relatively infrequent phenomenon in the traditional marriage. In 1887 , there was only one divorce for every 17.3 marriages (Mihanovich et al., 1952, p. 326). Both internal and external pressures militated against divorce as a choice of action. With greater emphasis on personality involvement and fulfillment, the risks for failure increase. Fulfillment in marriage has become a goal in itself. Although the preponderance of marriages still remain intact, the divorce rate has increased to the point where now one of four marriages fails. In such marriages the partners find it impossible for one reason or another to make the necessary adjustment, or the marriage does not seem to one, or both, to be worth the effort of such adjustments (Bernard, p. 721). 
Significance of VA in Marriage

As noted earlier, communication in marriage is both verbal and non-verbal. Verbal communication has received considerable attention from the behavioral sciences and social work because it is the principal tool used in social work and psychotherapy. Ideally, verbal communication permits accurate exchange of ideas and feelings with excellent possibilities for correcting distortions of messages by both sender and receiver.

It has been found that VA as an aspect of verbal communication is directly related to general emotional health, or personality organization.

A mature level of organizational unity implies two correlated processes: (a) That the differentiation of attitudes within the personality has proceeded at a normal expectable rate; and (b) Integrative mechanisms have kept pace so that despite his increasing internal complexity, the person nevertheless remains well-coordinated (Polansky, 1965, p. 42).

The constructive use of communication by the healthy personality may play a key role in maintaining a viable relationship and serve to promote socialization and personality development. In the normal or happy marriage, high VA could conceivably promote maintenance of the marital relationship. This kind of relationship, in which socialization and personality development takes place, may be a reasonably good definition of love, and gives support to the folk 
wisdom that happiness can never be an end in itself but is a result of growth and achievement.

By definition VA is capable of tapping the inner self. The emotionally healthy person presumably has high VA and thus, is not fearful of disclosing determinant attitudes and feelings; and further, the well integrated person is not parasitically involved in a relationship. However, all marital relationships are subjected to periodic stress and situational crises. It is perhaps here that high VA becomes an important factor. Perhaps the most important tool in the beginning and middle phase of problem solving is the use of words in service of constructive attitudes. The third phase would see the translation of expressed attitudes into positive problemsolving behavior and the restoration of the briefly disturbed relationship to its homeostatic balance. This is the opposite of the alienation process in which divorce is the end product of an entire process of alienation. In this latter process, the opposite of what we have described takes place. As each relationship crisis remains unresolved, the relationship spirals into greater and greater alienation and finally complete rupture in divorce.

However, it has been suggested by Ichhieser (1949) that in good relationship a portion of the inner self often remains invisible in order to protect relationship and mutual self-esteem. The originally destructive tendencies are fed through some kind of transformer, 
which renders them useful for constructive verbalization and behavior.

It may be that the concept of another is as important a variable in determining the quality of relationship as verbal accessibility.

"It has been shown... that when persons receive contradictory information about another they often misperceive entire sets of facts in order to develop an internally consistent view of that person . . (and). - provide themselves with a picture of the other which remains relatively stable and consistent" (Levinger and Senn, p. 10). We feel that effective VA operates in such a way that the expression of feelings, impulses and attitudes inimical to a good relationship are modified or controlled.

Thus, we conclude that the healthy personality will have, under most conditions, an adequately functioning VA system which discriminates the material to be verbalized in terms of situation and target person. We reason that the healthy personality will discipline VA in terms of roles and relationship in marriage.

\section{Recommendations for Future Research}

This study points up the necessity of studying communication and VA in conjunction with other variables. VA appears to be a personality characteristic, and the combination of personality measures and VA scale would probably produce a more accurate measure of 
VA of the person. This should be strengthened by observational data as well as reports from significant target persons.

We have also pointed out that marriage and marital satisfaction have many components and many determinants. Also, marriage is an open system and cannot be studied in isolation. Since all interaction is some form of communication, and verbal interaction and VA patterns are just one perspective on interaction, we suggest that VA in marriage be studied in various "styles" of marriage, i.e. traditional, companionship, and the like.

Assuming a traditional orientation to marriage, it may be important that one partner, the female, have passive tendencies and low positive VA. Thus, the orientation to marriage might be a factor in determining the patterns of verbal interaction.

Another approach to the study of VA in marriage might be by sampling marital partners within defense oriented interactional patterns, such as sado-masochistic, dominant-submissive, and the like.

Further research might investigate the type of clients served by the conciliation service. We suspect that these marriages are characterized by traditional roles, or at the very least, symbiotic, pathological patterns of interaction. Diagnostic case studies might be used in this approach. The Court sample might also be used to study the characteristics of and verbal communication patterns between respondents and petitioners. 
A research project could be designed to study the function of communication and VA in marriage. A Court sample might be used to study the function of VA in the alienation and divorce process. Finally, we suggest that future research make use of a normal sample. Data from a normal sample would serve to test the idea that VA is positively related to personality organization. Types of VA, attitude areas of VA, and functions of VA in satisfactory marriages could be compared with those in pre-divorce marriages. 


\section{BIBLIOGRAPHY}

1. Bell, Robert R. Marriage and family interaction. Homewood, Illinois, Dor sey Press, 1963. 465 p.

2. Bernard, Jessie. The adjustment of married mates. In:

Christensen's Handbook of marriage and the family. Chicago, Rand McNally, 1964. p. 675-739.

3. Blood, Robert O. and Donald M. Wolfe. In: Christensen's Handbook of marriage and the family. Chicago, Rand McNally, 1964. $1028 \mathrm{p}$.

4. Breedlove, James L. A diagnostic study of marriage. Doctoral Thesis. Cleveland, Western Reserve University, 1962. 140 leaves.

5. Buber, Martin. I and thou. New York, Charles Scribner's Sons, 1958. $137 \mathrm{p}$.

6. Burgess, Ernest W. Engagement and marriage. Chicago, J. B. Lippincott, 1953. $819 \mathrm{p}$.

7. The family as a unity of interacting per sonalities. The Family, VII:3-10. March 1926.

8. Burgess, Ernest W. and Harvey J. Locke. The family. New York, American Book Company, 1950. 800 p.

9. Burdick, Harry, and Alan Burnes. A test of strain toward symmetry theories. Journal of Abnormal and Social Psychology LVII:367-370. November, 1958.

10. Christensen, Harold T., editor. Handbook of marriage and the family. Chicago, Rand McNally, 1964. 1028 p.

11. Cottrell, Leonard and Nelson Foote. Identity and interpersonal competence. Chicago, University of Chicago, 1955. 305 p.

12. Edwards, Allen A. Techniques of attitude scale construction. New York, Appleton-Century-Crofts, 1957. 256 p.

13. Farber, Bernard. Family organization and interaction. San Francisco, Chandler, 1964. 536 p. 
14, Fiedler, F. E. Assumed similarity mea sures as predictors of team effectiveness. Journal of Abnormal and Social Psychology XLI: $381-388$. July 1954.

15. Goffman, Erving. The presentation of self in everyday life. Garden City, New York, Doubleday, 1959. 259 p.

16. Goode, William J. After divorce. Glencoe, Illinois, Free Press, 1966. $381 \mathrm{p}$.

17. - Family disorganization. In: Merton and

Nisbit's Contemporary social problems. New York, Harcourt, Brace, 1966. p. 479-553.

18. Green, Bert F. Attitude measurement. In: Lindzey's Handbook of social psychology. Cambridge, Massachusetts, Addison-Wesley, 1954. p. 352-382.

19. Green, Kenneth. The echo of marital conflict. Family Process 2:315-328. September 1963.

20. Hollingshead, A. B. Cultural factors in the selection of marriage mates. American Sociological Review XV:619-627. 19.50.

21. Ichheiser, Gustav, Misunderstandings in human relations. The American Journal of Sociology, Vol. XV No. 2, September 1949. $70 \mathrm{p}$.

22. Jacobson, Paul H. American marriage and divorce. New York, Rinehart and Company, 1959. $188 \mathrm{p}$.

23. Jolesch, Miriam. Casework treatment of young married couples. Social Casework XLIII:245-251. 1962.

24. Jourard, Sidney M. and Paul Lasakow. Some factors in selfdisclosure. Journal of Abnormal and Social Psychology 56:91 98. 1958.

25. Jourard, Sidney M. The transparent self. New York, Van Nostrand, 1964. $200 \mathrm{p}$.

26. Karlsson, Georg. Adaptability and communication in marriage. 2 ed. New Jersey, Bedminster Press, 1963. 89 p. 
27. Karr, Chadwick. Unpublished Research. Court of Domestic Relations, Multnomah County. Portland, Oregon, 1966.

28. Katz, Myer. Agreement on connotative meaning in marriage. Family Process 4:64-74. March, 1965.

29. Kernodle, Wayne. Some implications of the homogamy complementary needs theories of mate selection for sociological research. Social Forces 38:145-152. December 1959.

30. Komarovsky, Mirra. Blue-collar marriage. New York, Random House, 1964. 395 p.

31. Kresse, Barbara F. et al. A scale of verbal accessibility in marriage. Master's thesis. Portland, Portland State College School of Social Work, 1967. 89 leaves.

32. Landis, Judson T. In: Christensen's Handbook of marriage and the family. Chicago, Rand McNally, 1964. 1028 p.

33. Levinger, George. Marital cohesiveness and dissolution: an integrative review. Journal of Marriage and the Family $27: 19-28.1965$.

34. Levinger, George and David J. Senn. Disclosure of feelings in marriage. Unpublished research. University of Massachusetts. n.d. $12 \mathrm{p}$.

35. Mayer, John E. The invisibility of married life. New Society 9:272-273. 1967.

36. Mihanovich, Clement Simon, Gerald J. Schnepp, John L. Thomas. Marriage and the family. Milwaukie, Bruce, 1952. $502 \mathrm{p}$.

37. Montagu, Ashley M. F. Marriage a cultural perspective. In: Eisenstein's Neurotic interaction in marriage. New York, Basic Books Incorporated, 1956. p. 1-9.

38. Navran, Leslie. Communication and adjustment in marriage. Family Process VI: 173-185. September, 1967.

39. Official Records of the Conciliation Service, Court of Domestic Relations, Multnomah County, Portland, Oregon, 1964-1967. 
40. Polansky, Norman A. The concept of verbal accessibility. Smith College Studies in Social Work 36:1-48. 1965.

41. Pugh, Lucille S. et al, Marital interaction theory: some implications for research. Master's thesis. Portland, Portland State College School of Social Work. 1966. 115 leaves.

42. Reiner, Beatrice and Irving Kaufman. Character disorders in the parents of delinquents. New York, Family Service Association of America, 1959. 179 p.

43. Roberts, Robert. The diagnostic process. In: Family Service Association of America Research Project on the Treatment of Marital Problems, New York, 1965. 58 p.

44. Rollins, B. C. Values consensus and cohesion in the husbandwife dyad. Doctoral thesis. Ithaca, Cornell University. 1961.

45. Ruesch, Jurgen and Gregory Bateson. Communication: the social matrix of psychiatry. New York, Norton, 1951. 314 p.

46. Satir, Virginia. Conjoint family therapy. Palo Alto, California, Science and Behavior Books, 1964. 196 p.

47. Smith, A. J. Perceived similarity and the projection of similarity: the influence of valence. Journal of Abnormal and Social Psychology:376-380. November, 1958.

48. Spitz, Rene A. No and yes; on the genesis of human communication. New York, International Univer sities Press, 1957. $170 \mathrm{p}$.

49. Steiner, Ivan. A comparison of two techniques employed in the study of interpersonal perception. Sociometry:1-7. March, 1957.

50. - Interpersonal behavior as influenced by accuracy of social perception. Psychological Review:268274. July, 1955.

51. Stouffer, Samuel A. et al. Studies in social psychology in World War II. Vol. 4: Measurement and prediction. Princeton, Princeton University Press, 1950. $756 \mathrm{p}$. 
52. Stryker, Sheldon. Symbolic interaction as an approach to family research. Marriage and Family Living 21:111-119. 1959.

53. - The interactional and situational approaches. In: Christensen's Handbook of marriage and the family. Chicago, Rand McNally, 1964. pp. 125-170.

54. Taylor, Dalmas and Irwin Altman. Intimacy-scaled stimuli for use in studies of interpersonal relationships. Bethesda, Maryland, Naval Medical Research Institute, 1966. 54 p.

55. Vesper, Sue and Frankie Spearman. Distortion of roles--a factor in marital imbalance. In: Centennial Papers St. Louis Family and Children's Service Centennial Institute 1960. pp. $1-14$.

56. Vygotskii, Lev S. Thought and language. Cambridge, M. I. T. Press, 1962. $168 \mathrm{p}$.

57. Weiss, Viola and R. Monroe. A framework for understanding family dynamics: part I. Social Casework 40:3-9, 1959. 
APPENDICES 
APPENDIX A 


\section{INSTRUCTIONS TO SUBJECTS}

(The following instructions were not read verbatim but were used as a frame of reference by interviewers.)

\section{PART I}

We are asking you to take part in a research project having to do with the readiness of husbands and wives to talk concerning their feelings about a variety of subjects. Although there may be quite a few items that do not directly apply to your particular situation, I would like you to respond to the items as if they did apply to your marriage. I am not so much interested in what is actually happening in your marriage as in how much you feel free to discuss your true feelings with your husband or wife.

The value of this research project will be greatly increased if you reveal as accurately as possible your true feelings about whether you would or would not talk about any particular item or items.

This project will in no way effect the counseling for which you are here; and you, as an individual, will not be graded or evaluated by me or anyone else. To protect your identity, I will in no way connect your name with the final results of the research. Instead, I will use a number. I am also under the same professional requirements for confidentiality as the counselor to whom you have already talked or will shortly be talking to.

I hope that you will see this as an opportunity to take part in 
the important business of increasing the understanding of communication in marriage.

This deck of cards contains the subjects that are to be covered in this project. As I read from my questionnaire, you may read the card before you that contains the identical statement.

On the box are four slots for these cards: one to indicate you would talk completely with your husband or wife about the subject; one to indicate you would talk a lot to him/her; one to show you would talk a little; and one to shøw you would say nothing about the subject to $\mathrm{him} / \mathrm{her}$.

As soon as I have read the statement aloud and you have looked at the card, please place that card in the slot that most clearly shows how much you would be willing to talk with your husband/wife about the subject. Please keep in mind, as we proceed, that you will not be graded on your responses to the se subjects and that I am interested in not only your willingness to talk with your husband/wife, but also in your unwillingness to do so.

We might practice on one subject that is shown on the white card before you: "Please show how much you would talk with your husband/wife about your feelings concerning the way he/she has changed since your marriage." Now, place the card in the proper slot. To save time, I will not repeat the statement: "Please show how much you would be willing to talk with your husband/wife about 
your feelings concerning .. " that appears on your cards before every item. I will repeat it from time to time merely as a reminder. Do you have any questions before we go on to the rest of the items?

\section{PAR T II}

The second part of this project concerns your opinion of how much your husband/wife would talk with you about a variety of subjects. The same box will be used for you to show whether you think he/she would talk with you completely, a lot, a little, or none about, for example, "The way you have changed since your marriage." Again, your opinions will be confidential and will not be graded or used in the counseling for which you are here. 


\section{ATTITUDE STATEMENTS FOR HUSBAND}

Please show how much you would talk with your wife about your feelings concerning:

(Social Structure Items)

S 1 Differences in your religious beliefs

S 2 Fears you have about her mental condition

S 3 Successes in your work

S 4 Failures in your education

$S 5$ Your in-laws telling you how to raise your children

S 6 Your in-laws criticism of the way you live (house, auto, recreation)

S 7 Having too little time with your children

S 8 Your children taking too much of your time

S 9 How your wife handles money

Slo Her looking attractive when you go out

Sll The way she treats you in front of other people

S12 Improvements she could make in her appearance

S13 Her drinking too much at home or in public

Sl4 Her spending too much time "with the girls"

S15 Not being able to give her everything you would like to

S16 Fears you have of losing your job

S17 Wanting her to work or not to work

\section{(Interaction Items)}

I 1 Her attempts to dominate you through religion

I 2 Your in-laws doing too much for your family

I 3 Your in-laws taking too much of your time

I 4 Her hurting your parents' feelings 
I 5 Her thinking more of her parents than of you

I 6 Her putting the children's interests before yours

I 7 Her lack of interest in the children

I 8 Her ways of disciplining the children

I 9 Her criticizing you in front of the children

Ilo Her expecting too much of the children

I1 1 Her criticizing you

I1 2 Having to account for your time and activities

I1 3 Having no time you can call your own

I1 4 Her need to change some of her habits

I1 5 Her not paying attention to you

I16 Her demanding too much of your time

117 Her not respecting you as an individual

I18 Her failure to compliment you when you look nice

I19 Her interest in someone else

I20 Her lack of interest in having sex relations

I21 Her demands for sex relations too often

I22 Finding her sexually satisfying

I23 Her choice of friends

I24 Enjoyable things you could do together

I25 Material things seeming more important than you are

I26 Your interest in her work

I27 The way she nags you

(Personality Items)

$P \quad 1$ Your own feelings about God

$P 2$ Not being as successful in your work as you would like to be

P 3 Taking pride in doing your job well 
$P \quad 4$ Being unhappy in your job

P 5 Worries about your health

$P 6$ Concerns about your appearance

P 7 Fears that you may have a nervous breakdown

P 8 Things you do especially well (hobbies, recreation, etc.)

$P \quad$ Feelings that you can't do many things right

Plo The way you get along with other people

Pll Your sex life before marriage

Pl2 Your hopes for the future

Pl3 Pleasant thoughts you would like to express

Pl4 Thoughts you have difficulty controlling

P15 Things that make you feel good

P16 Things about yourself that you dislike or are ashamed of 


\section{ATTITUDE STATEMENTS FOR WIFE}

Please show how much you would talk with your husband about your feelings concerning:

(Social Structure Items)

S 1 Differences in your religious beliefs

S 2 Fears you have about his mental condition

S 3 Successes in your work

S 4 Failures in your education

S 5 Your in-laws telling you how to raise your children

S 6 Your in-laws criticism of the way you live (house, auto, recreation)

S 7 Having too little time with your children

S 8 Your children taking too much of your time

S 9 How your husband handles money

Slo His looking attractive when you go out

Sll The way he treats you in front of other people

S12 Improvements he could make in his appearance

S13 His drinking too much at home or in public

S14 His spending too much time "with the boys"

S15 Not being able to give him everything you would like to

S16 Fears you have of losing your job

Sl7 Wanting to work or not wanting to work

\section{(Interaction Items)}

I 1 His attempts to dominate you through religion

I 2 Your in-laws doing too much for your family

I 3 Your in-laws taking too much of your time

I 4 His hurting your parents' feelings 
I 5 His thinking more of his parents than of you

I 6 His putting the children's interests before yours

I 7 His lack of interest in the children

I 8 His ways of disciplining the children

I 9 His criticizing you in front of the children

Il $0 \mathrm{His}$ expecting too much of the children

Il 1 His criticizing you

I1 2 Having to account for your time and activities

I1 3 Having no time you can call your own

I1 4 His need to change some of his habits

Il 5 His not paying attention to you.

Il $6 \mathrm{His}$ demanding too much of your time

Il 7 His not respecting you as an individual

I1 8 His failure to compliment you when you look nice

I19 His interest in someone else

I20 His lack of interest in having sex relations

I2l His demands for sex relations too often

I22 Finding him sexually satisfying

I23 His choice of friends

I24 Enjoyable things you could do together

I25 Material things seeming more important than you are

I26 Your interest in his work

I27 The way he nags you

(Personality Items)

$P \quad 1$ Your own feelings about God

P 2 Not being as successful in your work as you would like to be

P 3 Taking pride in doing your job well 
$P \quad 4$ Being unhappy in your job

P 5 Worries about your health

P 6 Concerns about your appearance

$P 7$ Fears that you may have a nervous breakdown

P 8 Things you do especially well (hobbies, recreation, etc.)

$P 9$ Feelings that you can't do many things right

P10 The way you get along with other people

Pll Your sex life before marriage

Pl2 Your hopes for the future

P13 Pleasant thoughts you would like to express

Pl4 Thoughts you have difficulty controlling

P15 Things that make you feel good

P16 Things about yourself that you dislike or are a shamed of 


\section{ATTITUDE STATEMENTS FOR HUSBAND'S ESTIMATE OF WIFE'S VA}

(Randomized in the order presented to subjects)

Please show how much your wife would talk with you about her feelings concerning:

I 6 Your putting the children's interests before hers

S 4 Failures in her education

I 24 Enjoyable things you could do together

I 4 Your hurting her parents' feelings

I 19 Your interest in someone else

I 7 Your lack of interest in the children

S 8 The children taking too much of her time

I 17 Your not respecting her as an individual

P 5 Worries about her health

I 3 Your parents taking too much of your time

I 26 Her interest in your work

P16 Things about herself that she dislikes or is a shamed of

I 16 Your demanding too much of her time

I 8 Your ways of disciplining the children

I 5 Your thinking more of your parents than of her

I 21 Your demands for sex relations too of ten

P 6 Concerns about her appearance

Sll The way you treat her in front of other people

I 18 Your failure to compliment her when she looks nice

$\mathrm{S} 12$ Improvements you could make in your appearance

I 10 Your expecting too much of the children

S 6 Your parents' criticism of the way you live (house, auto, recreation)

P15 Things that make her feel good 
S13 Your drinking too much at home or in public

Sl4 Your spending too much time "with the boys"

S15 Her not being able to give you everything she would like to

Plo The way she gets along with other people

P 3 Taking pride in doing her job well

I 27 The way you nag her

P 1 Her own feelings about God

I 22 Finding you sexually satisfying

P 7 Fears that she may have a nervous breakdown

Pl4 Thoughts she has difficulty controlling

S I Differences in your religious beliefs

S 5 Your parents telling her how to raise the children

I 13 Having no time she can call her own

I 23 Your choice of friends

P13 Pleasant thoughts she would like to express

$P 2$ Not being as successful in her work as she would like to be

Sl7 Wanting to work or not wanting to work

$P 4$ Being unhappy in her job

Pll Her sex life before marriage

S 9 How you handle money

I 14 Your need to change some of your habits

S 7 Her having too little time with the children

I 20 Your lack of interest in having sex relations

I 12 Having to account for her time and activities

S 2 Fears she may have about your mental condition

I 1 Your attempts to dominate her through religion

Pl2 Her hopes for the future

I 15 Your not paying attention to her

S16 Fears she has of losing her job 
I 9 Your criticizing her in front of the children

I 2 Your parents doing too much for your family

P 8 Things she does especially well (hobbies, recreation, etc.)

I 11 Your criticizing her

$P 9$ Feelings that she can't do many things right

I 25 Material things seeming more important than she is

S 3 Successes in her work

Slo Your looking attractive when you go out 


\section{ATTITUDE STATEMENTS FOR WIFE'S ESTIMATE OF HUSBAND'S VA}

(Randomized in the order presented to subjects)

Please show how much your husband would talk with you about his feelings concerning:

I 12 Having to account for his time and activities

I 14 Your need to change some of your habits

I 15 Your not paying attention to him

P 8 Things he does especially well (hobbies, recreation, etc.)

$P 9$ Feelings that he can't do many things right

Sl 4 Your spending too much time "with the girls"

I 23 Your choice of friends

I 2 Your parents doing too much for your family

I 24 Enjoyable things you could do together

$P 2$ Not being as successful in his work as he would like to be

S16 Fears he has of losing his job

I 7 Your lack of interest in the children

I 10 Your expecting too much of the children

I 3 Your parents taking too much of your time

I 4 Your hurting his parents' feelings

I 11 Your criticizing him

I 21 Your demands for sex relations too often

I 1 Your attempts to dominate him through religion

$P 7$ Fears that he may have a nervous breakdown

Plo The way he gets along with other people

P14 Thoughts he has difficulty controlling

P15 Things that make him feel good

I 13 Having no time he can call his own

Pll His sex life before marriage 
S12 Improvements you could make in your appearance

I 5 Your thinking more of your parents than of him

I 6 Your putting the children's interests before his

P 5 Worries about his health

P 6 Concerns about his appearance

I 17 Your not respecting him as an individual

I 9 Your criticizing him in front of the children

S 7 His having too little time with the children

S 8 The children taking too much of his time

I 16 Your demanding too much of his time

S 3 Successes in his work

I 8 Your ways of disciplining the children

I 18 Your failure to compliment him when he looks nice

I 19 Your interest in someone else.

I 20 Your lack of interest in having sex relations

S 4 Failures in his education

S13 Your drinking too much at home or in public

S15 His not being able to give you everything he would like to

I $26 \mathrm{His}$ interest in your work

I 27 The way you nag him

$P \quad 1$ His own feelings about God

S 9 How you handle money

S 6 Your parents' criticism of the way you live (house, auto, recreation)

S 1 Differences in your religious beliefs

S17 Wanting you to work or not to work

Pl2 His hopes for the future

S 2 Fears he has about your mental condition

Pl3 Pleasant thoughts he would like to express

Slo Your looking attractive when you go out 
I 25 Material things seeming more important than he is

$P \quad 3$ Taking pride in doing his job well

P 4 Being unhappy in his job

Pl6 Things about himself that he dislikes or is a shamed of

Sll The way you treat him in front of other people

I 22 Finding you sexually satisfying

S 5 Your parents telling him how to raise the children 
VA SCORE SHEET

Couple No.

13

Reconciliation Refused $\checkmark$

Respondent:

Husband Wife Reconciliation Effected

Off-Schedule

For: Husband Wife

\begin{tabular}{|c|c|c|c|c|c|c|c|c|c|c|c|c|c|c|c|c|c|c|c|}
\hline & \multicolumn{3}{|c|}{ Self } & \multicolumn{5}{|c|}{ Spouse Est } & \multirow{2}{*}{$d$} & \multicolumn{5}{|c|}{ Self } & \multicolumn{4}{|c|}{ Spouse Est } & \multirow{2}{*}{$d$} \\
\hline & 3 & 2 & \begin{tabular}{l|l}
1 & 0
\end{tabular} & 0 & 3 & 2 & 1 & 0 & & & 3 & 2 & 1 & 0 & 3 & 32 & 1 & 0 & \\
\hline$\overline{\mathrm{S} 1}$ & 3 & & & & & & 1 & & 2 & 14 & 3 & & & & & 2 & & & 1 \\
\hline 2 & 3 & & & & & & & 0 & 3 & $15 \mid$ & & 2 & & & & 2 & & & 0 \\
\hline 3 & 3 & & & + & & & 1 & & 2 & $16 \mid$ & 3 & & & & 3 & & & & 0 \\
\hline 4 & 3 & & & & & 2 & & & 1 & 17 & 3 & & & & & 2 & & & 1 \\
\hline 5 & & 2 & & & & 2 & & & 0 & 18 & 3 & & & & & 2 & & & 1 \\
\hline 6 & 3 & & & & & 2 & & & 1 & 19 & 3 & & & & 3 & & & & 0 \\
\hline 7 & 3 & & & & & & 1 & & 2 & 20 & 3 & & & & & 2 & & & 1 \\
\hline 8 & 3 & & & & 3 & & & & 0 & 21 & 3 & & & & & 2 & & & 1 \\
\hline 9 & 3 & & & 0 & 3 & & & & 0 & 22 & 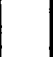 & 2 & & & + & 2 & & & 0 \\
\hline 10 & 3 & & & + & & & 1 & & 2 & 23 & 3 & & & & 0 & & & & 0 \\
\hline 11 & 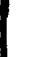 & 2 & & 0 & & 2 & & & 0 & 24 & 3 & & & & + & 2 & & & 1 \\
\hline 12 & 3 & & & & & 2 & & & 1 & 25 & 3 & & & & & 2 & & & 1 \\
\hline 13 & 3 & & & & & & 1 & & 2 & 26 & & 2 & & & + & 2 & & & 0 \\
\hline 14 & 3 & & & & 3 & & . & & 0 & 27 & 3 & & & & & 2 & & & 1 \\
\hline 15 & 3 & & & & & & 1 & & 2 & $\mathrm{Pl}$ & 3 & & & & 0 & & 1 & & 2 \\
\hline 16 & 3 & & & & 3 & & & & 0 & 2 & 3 & & & & & 2 & & & 1 \\
\hline 17 & 3 & & & 0 & & 2 & & & 1 & 3 & 3 & & & & +1 & 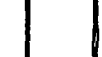 & 1 & & 2 \\
\hline $\mathrm{Il}$ & & 2 & & & & & & 0 & 2 & 4 & 3 & & & & & 2 & & & 1 \\
\hline 2 & & 2 & & & 3 & & & & 1 & 5 & & & 1 & & & 2 & & & 1 \\
\hline$\not 1$ & 11 & 111 & $1 / 1 /$ & $1 / 11$ & 11 & $1 /$ & $1 / 1$ & 11 & $1 /$ & 6 & 3 & & & & & & 1 & & 2 \\
\hline 4 & 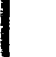 & & 1 & & & 2 & & & 1 & 7 & & & & 0 & 3 & 3 & & & 3 \\
\hline 5 & 3 & & & & 3 & & & & 0 & 8 & & & 1 & & + & 2 & & & 1 \\
\hline 6 & 3 & & & & & 2 & & & 1 & 9 & & & 1 & & & 2 & & & 1 \\
\hline 7 & 3 & & & & & 2 & & & 1 & 10 & & 2 & & & 0 & & 1 & & 1 \\
\hline 8 & 3 & & & 0 & & & 1 & & 2 & $x x$ & $1 /$ & $1 / 1$ & 11 & $1 / 1$ & $1 / 1$ & $1 / 1 /$ & 111 & $1 /$ & 1111 \\
\hline 9 & 3 & & & & & & 1 & & 2 & 12 & 3 & & & & $+\|$ & 2 & & & 1 \\
\hline 10 & 3 & & & & & & 1 & & 2 & 13 & 3 & & & & + & 2 & & & 1 \\
\hline 11 & & 2 & & & & 2 & & & 0 & 14 & & 2 & & & & 2 & & & 0 \\
\hline 12 & 3 & & & & & & 1 & & 2 & 15 & & 2 & & & & & 1 & & 1 \\
\hline$|\not| b \mid$ & 11 & 1 & & 11 & $1 / 1$ & 11 & $1 / 1$ & 11 & $1 /$ & 16 & & 2 & & & & & 1 & & 1 \\
\hline
\end{tabular}

$\Sigma$ OVA $=19 \quad \Sigma-$ VA 104

Total VA $=148$ 
VA SCORE SHEET

Couple No.

13

Respondent:

Husband Wife

Reconciliation Refused $V$

Reconciliation Effected

Off-Schedule

For: Husband

\section{Wife}

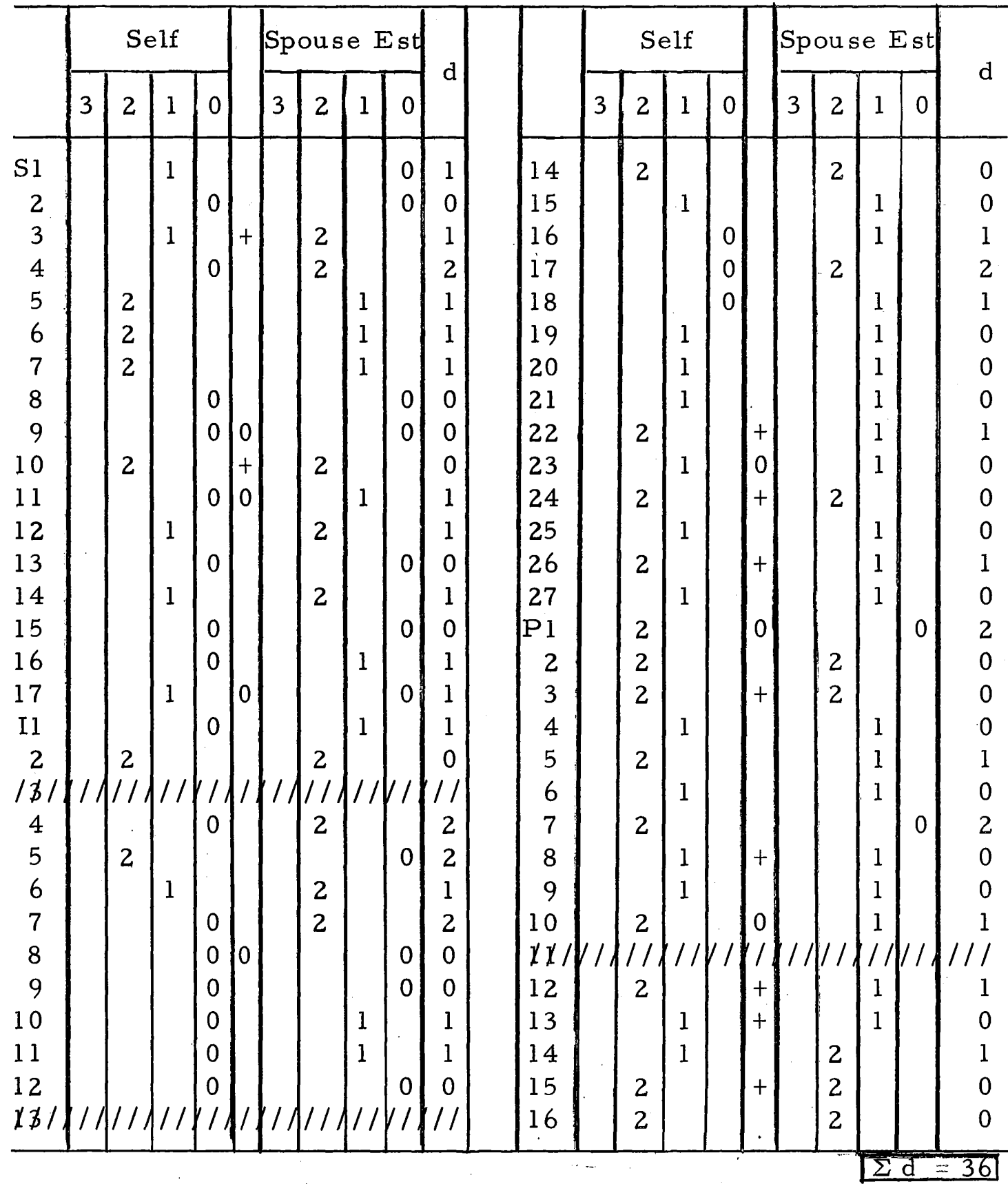

$\Sigma+V A=17 \quad \Sigma+\xi O V A=23$

$\Sigma O V A=6$

$\begin{aligned} & I-V A=34 \\ & \text { TotaI VA }=57\end{aligned}$ 
APPENDIX B 
TABLE XI

HUSBANDS AND WIVES' MEDIAN RESPONSES TO

ATTITUDE STATEMENTS

\begin{tabular}{lccc}
\hline Item & Item & Median & $\begin{array}{c}\text { Differences } \\
\text { between } \\
\text { No. }\end{array}$ \\
\hline
\end{tabular}

\section{Social Structure}

S 1 Differences in your religious

beliefs

$1.09+1.33+.24$

2 Fears you have about his/her mental condition

$2.07 \quad 1.28 \quad-.79$

3 Successes in your work

$2.50 \quad 1.70 \quad-.80$

4 Failures in your education

1.40

$1.93+.53$

5 Your in-laws telling you how to raise your children

$2.00 \quad 1.25-.75$

6 Your in-laws' criticism of the way you live (house, auto, rec.)

$1.21-1.12-.09$

7 Having too little time with your children

$2.10 \quad 1.88-.22$

8 Your children taking too much of your time

$1.21+1.39+.18$

9 How your wife/husband handles money

2.69

$2.17-.52$

$10 \mathrm{His} /$ her looking attractive when you go out
2.13
2.13
.00

11 The way he/she treats you in front of other people

1.83

$1.61-.22$

12 Improvements he/she could make in his/her appearance

$1.14 \quad 1.39+.25$

13 His/her drinking too much at home or in public

$1.50 \quad 1.70+.20$

$14 \mathrm{His} / \mathrm{her}$ spending too much time with the "boys"/"girls"

$1.61 \quad 1.50 \quad-.11$


TABLE XI (continued)

\begin{tabular}{|c|c|c|c|c|}
\hline \multirow{2}{*}{$\begin{array}{c}\text { Item } \\
\text { No. }\end{array}$} & \multirow{2}{*}{ Item } & \multicolumn{2}{|c|}{ Median } & \multirow{2}{*}{$\begin{array}{c}\text { Differences } \\
\text { between } \\
\text { Median }\end{array}$} \\
\hline & & Husbands & Wives & \\
\hline
\end{tabular}

15 Not being able to give him/ her everything you would like to

$\begin{array}{rrr}2.00 & 1.50 & -.50 \\ 1.21 & .50 & -.71\end{array}$

17 Wanting her to work or not to work... wanting to work or not wanting to work

$2.50 \quad 1.30 \quad-1.20$

\section{$\underline{\text { Interaction }}$}

I 1 His/her attempts to dominate you through religion

$\begin{array}{lll}1.80 & 1.30 & -.50 \\ 1.50 & 1.72 & +.22\end{array}$

3 Your in-laws taking too much of your time

Discarded

4 His/her hurting your parents' feelings

$1.27 \quad 1.37+.10$

5 His/her thinking more of his/ her parents than of you

$1.50 \quad 1.61+.11$

6 His/her putting the children's interests before yours

$1.41 \quad 1.86+.45$

7 His/her lack of interest in the children

$2.63 \quad 2.57-.06$

8 His/her ways of disciplining the children

$2.332 .63+.30$

9 His/her criticizing you in front of the children

$1.83 \quad 2.13+.30$

10 His/her expecting too much of the children

$1.62 \quad 2.21+.59$


TABLE XI (continued)

\begin{tabular}{cccc} 
Item & Item & Median & $\begin{array}{c}\text { Differences } \\
\text { between } \\
\text { No: }\end{array}$ \\
\hline
\end{tabular}

11 His/her criticizing you

1.33

$2.00+.67$

12 Having to account for your time and activities

$2.11 \quad 1.70 \quad-.41$

13 Having no time you can call your own

Discarded

$14 \mathrm{His} /$ her need to change some of his/her habits

$1.72 \quad 1.50-.22$

$15 \mathrm{His} / \mathrm{her}$ not paying attention to you

$1.41 \quad 1.50+.09$

$16 \mathrm{His} /$ her demanding too much of your time

$1.36 \quad 1.50+.14$

17 His/her not respecting you as an individual

$1.28+1.33+.05$

$18 \mathrm{His} /$ her failure to compliment you when you look nice

$1.38 \quad 1.13-.25$

$19 \mathrm{His} /$ her interest in someone else

1.88

$1.83-.05$

$20 \mathrm{His} /$ her lack of interest in having sex relations

$1.88 \quad 1.33-.55$

21 His/her demands for sex relations too often

$1.33+1.40+.07$

22 Finding him/her sexually satisfying

$\begin{array}{lll}2.00 & 1.93 & -.07 \\ 1.70 & 1.30 & -.40\end{array}$

24 Enjoyable things you could do together

2.30

$2.39+.09$

25 Material things seeming more important than you are

$1.50 \quad 1.59+.09$

26 Your interest in his/her work

1.63

$2.32+.69$

27 The way he/she nags you

1.33

$1.72+.39$ 
TABLE XI (continued)

\begin{tabular}{|c|c|c|c|c|}
\hline \multirow{2}{*}{$\begin{array}{l}\text { Item } \\
\text { No. }\end{array}$} & \multirow{2}{*}{ Item } & \multicolumn{2}{|c|}{ Median } & \multirow{2}{*}{$\begin{array}{c}\text { Differences } \\
\text { between } \\
\text { Median }\end{array}$} \\
\hline & & Husbands & Wives & \\
\hline \multicolumn{5}{|c|}{ Personality } \\
\hline P 1 & Your own feelings about God & 2.06 & 2.00 & -.06 \\
\hline 2 & $\begin{array}{l}\text { Not being as successful in your } \\
\text { work as you would like to be }\end{array}$ & 1.94 & 1.75 & -.19 \\
\hline 3 & $\begin{array}{l}\text { Taking pride in doing your job } \\
\text { well }\end{array}$ & 2.13 & 2.10 & -.03 \\
\hline 4 & Being unhappy in your job & 1.93 & 1.50 & $-i^{43}$ \\
\hline 5 & Worries about your health & 1.19 & 1.21 & +.02 \\
\hline 6 & Concerns about your appearance & 1.50 & 1.30 & -.20 \\
\hline 7 & $\begin{array}{l}\text { Fears that you may have a } \\
\text { nervous breakdown }\end{array}$ & 1.14 & 1.50 & +.36 \\
\hline 8 & $\begin{array}{l}\text { Things you do especially well } \\
\text { (hobbies, recreation) }\end{array}$ & 1.88 & 1.40 & -.40 \\
\hline 9 & $\begin{array}{l}\text { Feelings that you can't do } \\
\text { many thing s right }\end{array}$ & 1.50 & 1.63 & +.13 \\
\hline 10 & $\begin{array}{l}\text { The way you get along with } \\
\text { other people }\end{array}$ & 1.75 & 1.42 & -.33 \\
\hline 11 & Your sex life before marriage & \multicolumn{3}{|c|}{ Discarded } \\
\hline 12 & Your hopes for the future & 2.50 & 2.20 & -.30 \\
\hline 13 & $\begin{array}{l}\text { Pleasant thoughts you would } \\
\text { like to express }\end{array}$ & 2.00 & 1.83 & -.17 \\
\hline 14 & $\begin{array}{l}\text { Thoughts you have difficulty } \\
\text { controlling }\end{array}$ & 1.39 & 1.36 & -.03 \\
\hline 15 & Things that make you feel good & 2.05 & 2.07 & +.02 \\
\hline 16 & $\begin{array}{l}\text { Things about yourself that you } \\
\text { dislike or are ashamed of }\end{array}$ & 1.72 & 1.42 & -.30 \\
\hline \multicolumn{5}{|c|}{$\mathrm{N}=57$} \\
\hline
\end{tabular}


TABLE XII

RESPONSES PER INTERVAL AND MEDIAN RESPONSES OF 26 HUSBANDS AND 26 WIVES TO SOCIAL STRUCTURE ITEMS

\begin{tabular}{|c|c|c|c|c|c|c|c|c|c|c|}
\hline \multirow{2}{*}{$\begin{array}{c}\text { Item } \\
\text { No. }\end{array}$} & \multicolumn{5}{|c|}{ Husbands' Responses } & \multicolumn{5}{|c|}{ Wives' Responses } \\
\hline & $3 *$ & $2 *$ & $1 *$ & $0 *$ & Median & $3 *$ & $2 *$ & $1 *$ & $0 *$ & Median \\
\hline 1 & 5 & 3 & 12 & 6 & 1.09 & 9 & 3 & 6 & 8 & 1.33 \\
\hline 2 & 10 & 7 & 4 & 5 & 2.07 & 4 & 7 & 9 & 6 & 1.28 \\
\hline 3 & 13 & 3 & 8 & 2 & 2.50 & 5 & 10 & 7 & 4 & 1.70 \\
\hline 4 & 6 & 6 & 10 & 4 & 1.40 & 9 & 7 & 7 & 3 & 1.93 \\
\hline 5 & 9 & 8 & 5 & 4 & 2.00 & 4 & 7 & 8 & 7 & 1.25 \\
\hline 6 & 8 & 3 & 7 & 8 & 1.21 & 4 & 6 & 8 & 8 & 1.12 \\
\hline 7 & 11 & 5 & 6 & 4 & 2.10 & 8 & 8 & 6 & 4 & 1.88 \\
\hline 8 & 6 & 5 & 7 & 8 & 1.21 & 6 & 6 & 9 & 5 & 1.39 \\
\hline 9 & 16 & 5 & 3 & 2 & 2.69 & 10 & 9 & 4 & 3 & 2.17 \\
\hline 10 & 10 & 8 & 8 & 0 & 2.13 & 10 & 8 & 6 & 2 & 2.13 \\
\hline 11 & 9 & 6 & 8 & 3 & 1.83 & 5 & 9 & 6 & 6 & 1.61 \\
\hline 12 & 6 & 2 & 14 & 4 & 1.14 & 6 & 6 & 9 & 5 & 1.39 \\
\hline 13 & 9 & 4 & 2 & 11 & 1.50 & 9 & 5 & 7 & 5 & 1.70 \\
\hline 14 & 5 & 9 & 7 & 5 & 1.61 & 8 & 5 & 8 & 5 & 1.50 \\
\hline 15 & 7 & 12 & 5 & 2 & 2.00 & 6 & 7 & 7 & 6 & 1.50 \\
\hline 16 & 7 & 4 & 7 & 8 & 1.21 & 4 & 4 & 5 & 13 & .50 \\
\hline 17 & 13 & 4 & 6 & 3 & 2.50 & 6 & 5 & 10 & 5 & 1.30 \\
\hline
\end{tabular}


TABLE XIII

RESPONSES PER INTERVAL AND MEDIAN RESPONSES OF 26 HUSBANDS AND 26, WIVES TO INTERACTION ITEMS

\begin{tabular}{|c|c|c|c|c|c|c|c|c|c|c|}
\hline \multirow{2}{*}{$\begin{array}{c}\text { Item } \\
\text { No. }\end{array}$} & \multicolumn{5}{|c|}{ Husbands' Responses } & \multicolumn{5}{|c|}{ Wives' Responses } \\
\hline & $3 *$ & $2 *$ & $1 *$ & $0 *$ & Median & $3 *$ & $2 *$ & $1 *$ & $0 *$ & Median \\
\hline 1 & 6 & 10 & 3 & 7 & 1.80 & 6 & 6 & 5 & 9 & 1.30 \\
\hline 2 & 8 & 5 & 7 & 6 & 1.50 & 6 & 9 & 4 & 7 & 1.72 \\
\hline 3 & \multicolumn{5}{|c|}{ Discarded } & \multicolumn{5}{|c|}{ Discarded } \\
\hline 4 & 3 & 7 & 13 & 3 & 1.27 & 9 & 3 & 8 & 6 & 1.37 \\
\hline 5 & 7 & 6 & 7 & 6 & 1.50 & 5 & 9 & 5 & 7 & 1.61 \\
\hline 6 & 6 & 6 & 11 & 3 & 1.41 & 6 & 11 & 5 & 4 & 1.86 \\
\hline 7 & 15 & 9 & 1 & 1 & 2.63 & 14 & 7 & 2 & 3 & 2.57 \\
\hline 8 & 12 & 6 & 7 & 1 & 2.33 & 15 & 5 & 2 & 4 & 2.63 \\
\hline 9 & 11 & 3 & 9 & 3 & 1.83 & 10 & 8 & 5 & 3 & 2.13 \\
\hline 10 & 9 & 5 & 8 & 4 & 1.62 & 11 & 7 & 4 & 4 & 2.21 \\
\hline 11 & 3 & 8 & 12 & 3 & 1.33 & 7 & 12 & 2 & 5 & 2.00 \\
\hline 12 & 8 & 13 & 2 & 3 & 2.11 & 5 & 10 & 7 & 4 & 1.70 \\
\hline 13 & \multicolumn{5}{|c|}{ Discarded } & \multicolumn{5}{|c|}{ Discarded } \\
\hline 14 & 6 & 9 & 10 & 1 & 1.72 & 7 & 6 & 11 & 2 & 1.50 \\
\hline 15 & 2 & 10 & 11 & 3 & 1.41 & 7 & 6 & 5 & 8 & 1.50 \\
\hline 16 & 6 & 6 & 7 & 7 & 1.36 & 7 & 6 & 4 & 9 & 1.50 \\
\hline 17 & 7 & 4 & 9 & 6 & 1.28 & 9 & 3 & 6 & 8 & 1.33 \\
\hline 18 & 4 & 6 & 8 & 8 & 1.38 & 7 & 3 & 8 & 8 & 1.13 \\
\hline 19 & 8 & 8 & 6 & 4 & 1.88 & 9 & 6 & 5 & 6 & 1.83 \\
\hline 20 & 8 & 8 & 5 & 5 & 1.88 & 7 & 5 & 6 & 8 & 1.33 \\
\hline 21 & 4 & 8 & 6 & 8 & 1.33 & 5 & 7 & 11 & 3 & 1.40 \\
\hline 22 & 9 & 8 & 7 & 2 & 2.00 & 9 & 7 & 6 & 4 & 1.93 \\
\hline 23 & 9 & 5 & 8 & 4 & 1.70 & 8 & 3 & 10 & 5 & 1.30 \\
\hline 24 & 11 & 10 & 3 & 2 & 2.30 & 12 & 9 & 3 & 2 & 2.39 \\
\hline 25 & 6 & 7 & 10 & 3 & 1.50 & 3 & 11 & 9 & 3 & 1.59 \\
\hline 26 & 7 & 7 & 9 & 3 & 1.63 & 11 & 11 & 2 & 2 & 2.32 \\
\hline 27 & 6 & 5 & 12 & 3 & 1.33 & 6 & 9 & 8 & 3 & 1.72 \\
\hline
\end{tabular}

* 3 signifies "completely, "2, "a lot," 1, "a little, "0, "none" 
TABLE XIV

RESPONSES PER INTERVAL AND MEDIAN RESPONSES OF 26 HUSBANDS AND 26 WIVES TO PERSONALITY ITEMS

\begin{tabular}{|c|c|c|c|c|c|c|c|c|c|c|}
\hline \multirow{2}{*}{$\begin{array}{c}\text { Item } \\
\text { No. }\end{array}$} & \multicolumn{5}{|c|}{ Husbands' Responses } & \multicolumn{5}{|c|}{ Wives' Responses } \\
\hline & $3 *$ & $2 *$ & $1 *$ & $0 *$ & Median & $3 *$ & $2 *$ & $1 \%$ & $0 *$ & Median \\
\hline 1 & 9 & 9 & 6 & 2 & 2.06 & 10 & 6 & 9 & 1 & 2.00 \\
\hline 2 & 8 & 9 & 6 & 3 & 1.94 & 7 & 8 & 10 & 1 & 1.75 \\
\hline 3 & 10 & 8 & 7 & 1 & 2.13 & 9 & 10 & 5 & 2 & 2.10 \\
\hline 4 & 9 & 7 & 6 & 4 & 1.93 & 6 & 2 & 10 & 8 & 1.50 \\
\hline 5 & 5 & 4 & 13 & 4 & 1.19 & 4 & 5 & 14 & 3 & 1.21 \\
\hline 6 & 6 & 7 & 10 & 3 & 1.50 & 6 & 5 & 10 & 5 & 1.30 \\
\hline 7 & 4 & 5 & 11 & 6 & 1.14 & 2 & 11 & 11 & 2 & 1.50 \\
\hline 8 & 8 & .. 8 & 8 & $\cdot 2$ & 1.88 & 6 & 6 & 11 & 3 & 1.40 \\
\hline 9 & 4 & 9 & 11 & 2 & 1.50 & 6 & 8 & 9 & 3 & 1.63 \\
\hline 10 & 7 & 8 & 9 & 2 & 1.75 & 7 & 5 & 13 & 1 & 1.42 \\
\hline 11 & \multicolumn{5}{|c|}{ Discarded } & \multicolumn{5}{|c|}{ Discarded } \\
\hline 12 & 13 & 9 & 4 & 0 & 2.50 & 10 & 10 & 3 & 3 & 2.20 \\
\hline 13 & 8 & 10 & 6 & 2 & 2.00 & 7 & 9 & 9 & 1 & 1.83 \\
\hline 14 & 6 & 6 & 9 & 5 & 1.39 & 7 & 5 & 7 & 7 & 1.35 \\
\hline 15 & 8 & 11 & 7 & 0 & 2.05 & 7 & 14 & 4 & 1 & 2.07 \\
\hline 16 & 6 & 9 & 7 & 4 & 1.72 & 5 & 7 & 12 & 2 & 1.42 \\
\hline
\end{tabular}

* 3 signifies "completely," 2 , "a lot, "1, "a little, "0, "none" 
TABLE XV

RANGE OF TOTAL VA SCORES $*$

\begin{tabular}{|c|c|c|}
\hline Couple No. & Hu sband & Wife \\
\hline 1 & 77 & 93 \\
\hline 2 & 96 & 74 \\
\hline 3 & 104 & 49 \\
\hline 4 & 111 & 83 \\
\hline 5 & 47 & 171 \\
\hline 6 & 118 & 58 \\
\hline 7 & 103 & 60 \\
\hline 8 & 101 & 78 \\
\hline 9 & 65 & 152 \\
\hline 10 & 63 & 41 \\
\hline 11 & 123 & 133 \\
\hline 12 & 122 & 126 \\
\hline 13 & 148 & 57 \\
\hline 14 & 58 & 112 \\
\hline 15 & 133 & 131 \\
\hline 16 & 68 & 107 \\
\hline 17 & 44 & 40 \\
\hline 18 & 99 & 117 \\
\hline 19 & 52 & 102 \\
\hline 20 & 119 & 58 \\
\hline 21 & 89 & 140 \\
\hline 22 & 129 & 91 \\
\hline 23 & 128 & 94 \\
\hline 24 & 64 & 121 \\
\hline 25 & 167 & 115 \\
\hline \multirow[t]{4}{*}{26} & 88 & 42 \\
\hline & $N=26$ & \\
\hline & Mean & 94.03 \\
\hline & Median & 93.50 \\
\hline
\end{tabular}

* The possible range was 0-171.

Range of total VA scores for husbands was 44-167.

Range of total VA scores for wives was 40-171. 